\title{
The Late Cretaceous transgression in the Saxonian Cretaceous Basin (Germany): old story, new data and novel findings
}

\author{
Markus Wilmsen, Birgit Niebuhr, Markus Fengler, Tobias Püttmann \\ \& Michaela Berensmeier
}

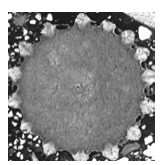

\begin{abstract}
The stratigraphy of the northwestern Saxonian Cretaceous Basin (Meißen-Niederau area) is revised based on integrated stratigraphic dating and facies analyses. The fauna of the Meißen Formation suggests that it is of early Middle Cenomanian age, rather than late Early Cenomanian as assumed hitherto. At Niederau, the basal Oberau Conglomerate of the Mobschatz Formation forms a contemporaneous equivalent of the Meißen Formation. The age, macro-/nannofossil content and transgressive nature link the bed to the early Middle Cenomanian Praeactinocamax primus Event. Up-section, the 70-m-thick Oberau-Gröbern composite section covers the Middle Cenomanian to Lower Turonian shown by nanno- and macrofossil data, substantiated by new carbon isotope analyses from the lower part of the section. The Middle to lower Upper Cenomanian isotope curve has been correlated to the Anglo-Paris and northern German basins, suggesting a stratigraphic gap in the Middle-Upper Cenomanian boundary interval that corresponds to a phase of sea-level fall (sequence boundary Cenomanian 4). The transgression history continued in the early Late Cenomanian with the upper Mobschatz Formation at Oberau-Gröbern, corresponding to the first onlap of the formation onto the Meißen Formation and basement rocks at Meißen-Zscheila. Another sea-level fall is recorded by the contact of the Mobschatz and Dölzschen formations in the mid-Upper Cenomanian (SB Ce 5), followed by a major deepening and siliciclastic starvation of the Meißen-Niederau area during the latest Cenomanian-earliest Turonian. The introduction of the Meißen-Dresden Subgroup is suggested for the lithologically uniform distal strata in order to compensate limitations of the current lithostratigraphic framework of the Elbtal Group. $•$ Key words: Elbtal Group, Cenomanian transgression, biostratigraphy, chemostratigraphy, sequence stratigraphy, lithostratigraphy.
\end{abstract}

Wilmsen, M., Niebuhr, B., Fengler, M., Püttmann, T. \& Berensmeier, M. 2019. The Late Cretaceous transgression in the Saxonian Cretaceous Basin (Germany): old story, new data and novel findings. Bulletin of Geosciences 94(1), 71-100 (12 figures, 1 table, appendix). Czech Geological Survey, Prague. ISSN 1214-1119. Manuscript received September 12, 2018; accepted in revised form March 1, 2019; published online March 21, 2019; issued March 31, 2019.

Markus Wilmsen \& Birgit Niebuhr, Senckenberg Naturhistorische Sammlungen Dresden (SNSD), Museum für Mineralogie und Geologie (MMG), Königsbrücker Landstraße 159, 01109 Dresden, Germany; markus.wilmsen@ senckenberg.de • Markus Fengler, Wiesenstraße 4, 01468 Moritzburg, Germany • Tobias Püttmann, Institut für Geologie, Mineralogie und Geophysik, Ruhr-Universität Bochum, Universitätsstraße 150, 44801 Bochum, Germany • Michaela Berensmeier, Institut für Paläontologie, Geozentrum, UZA II, Althanstraße 14, A-1090 Wien, Austria

In Saxony (eastern part of Germany), the area between Meißen, Dresden, Pirna and Bad Schandau is characterised by widespread strata of Late Cretaceous age, constituting the Cenomanian-Coniacian Elbtal Group. Current consensus on the course of the early Late Cretaceous transgression is that a first ingression from the northwest took place in the late Early Cenomanian (Meißen Formation). In the Middle Cenomanian, contemporaneous onlap is allegedly only documented by the fluvial Niederschöna Formation while marine strata are completely absent (see also Hancock 2004, p. 617). In the Late Cenomanian, marine onlap continued with two pulses of sea-level rise, i.e. in the $C$. naviculare and $M$. geslinianum ammonite zones, respectively (e.g. Voigt 1994, Tröger 2003). However, new observations such as the presence of a Middle Cenomanian index ammonite in the Meißen Formation (Wilmsen \& Nagm 2014) and the record of other presumably marine Middle Cenomanian strata (Tröger 2017) cast doubt on these interpretations. Here, we present new integrated stratigraphic and sedimentological data on the timing and extent of the marine inundation of the Saxonian part of the Saxo-Bohemian Cretaceous Basin from the Meißen-Niederau area, including the first evidence of the Praeactinocamax primus Event for Saxony. Furthermore, the results of this study require modifications of the current lithostratigraphy of the Elbtal Group. 


\section{Geological setting}

The early Late Cretaceous witnessed one of the largest marine transgressions of the Phanerozoic Eon (e.g. Hallam 1992). Large parts of Europe were covered by a shallow to moderately deep epicontinental sea with only some subordinate positive areas remaining (cf. Ziegler 1990, Philip \& Floquet 2000, Vejbæk et al. 2010). The MidEuropean Island (MEI) is one of these palaeogeographic key features of the Cretaceous in Central Europe, consisting of the Rhenish and Bohemian massifs (Fig. 1A, B). Approximately ESE-WNW-striking, it separates the northern temperate Boreal from the southern warmwater settings of the Tethyan Realm. Along the periphery of the MEI, some important sedimentary basins were located, preserving stratigraphic records crucial for the understanding of Cretaceous palaeontology and stratigraphy (e.g. Janetschke et al. 2015 for a recent summary). The Saxonian Cretaceous Basin (SCB) with its sedimentary infill, the Elbtal Group, is one of these basins (Fig. 1B, C).

The Elbtal Group (Voigt \& Tröger in Niebuhr et al. 2007) comprises Cenomanian to Middle Coniacian strata that have been deposited in a relatively narrow marine passage between the Osterzgebirge in the southwest (belonging to the Bohemian Massif) and the Westsudetic Island in the northeast (Fig. 1B, C). This strait opens towards the Boreal shelf in the northwest and via the Bohemian Cretaceous Basin (BCB) in the southeast to the Tethyan region, forming an important gateway between temperate and warm-water areas (cf. Wiese et al. 2004). The SCB may either be seen as the southeastern lobe of the Boreal north German shelf or as the northwestern extension of the BCB which formed an interface to the southern Tethyan Realm (Fig. 1B). However, the SCB retained a certain uniqueness as a self-contained basin. The Elbtal Group combines predominantly marine formations consisting of siliciclastics (nearshore sandstones), marly siltstones (Pläner) as well as hemipelagic marls and marly limestones; only the Middle Cenomanian Niederschöna Formation is of fluvial origin. Lithostratigraphic units documenting the complex Cenomanian onlap history of the Elbtal Group are the Meißen, Niederschöna, Mobschatz, Oberhäslich, Dölzschen and Pennrich formations (Fig. 2; lithostratigraphy follows, with emendations, Voigt \& Tröger in Niebuhr et al. 2007). Current consensus is that a first marine transgression from the northwest into the SCB occurred in late Early Cenomanian times, only reaching as far as the area around Meißen (Meißen Formation; Prescher \& Tröger 1989). Continued non-marine onlap is allegedly documented by the fluvial strata of the Middle Cenomanian Niederschöna Formation (e.g. Prescher 1957, Voigt 1998). Marine Middle Cenomanian strata have not been recorded previously, although Tröger (2017) suggested the existence of marine facies below the inferred Upper Cenomanian Mobschatz Formation in the northwestern part of the SCB.

During the Late Cenomanian, two major transgressions occurred in the Calycoceras naviculare and Metoicoceras geslinianum ammonite zones, respectively (Petrascheck 1900; Schander 1923; Häntzschel 1933; Tröger 1955; Voigt 1994; Voigt et al. 1994, 2006; Föhlisch 1998; Tröger 2003; Wilmsen et al. 2011; Wilmsen 2017), separating the West Sudetic Island from the mainland of the MEI, submerging a distinct relief of valleys and highs, and connecting the $\mathrm{SCB}$ to the $\mathrm{BCB}$. These Late Cenomanian transgressions, documented in the Mobschatz/Oberhäslich and Dölzschen/Pennrich formations, led to more homogeneous sedimentation patterns of a storm-influenced graded shelf during the Turonian (Voigt 1994, 1999, 2011). In the Meißen-Dresden area, offshore marls and Pläner prevailed (Brießnitz, Räcknitz and Strehlen formations; e.g. Tröger \& Wolf 1960, Tröger 1988), while the Elbsandsteingebirge was characterised by sandy nearshore facies (Schmilka, Postelwitz and Schrammstein formations), with a transitional zone (Faziesübergangszone) of the Pirna area in between (e.g. Voigt 1994, Tröger 2003, Janetschke \& Wilmsen 2014). The northeastern margin of the SCB as exposed today is tectonic in origin and represented by the NW-SE-striking Lausitz Thrust Fault, while the patchy occurrences of Cretaceous strata on the Osterzgebirge show the originally larger extent of marine deposition (Fig. 1C). Thickness and facies changes of strata of the Elbtal Group show that (with increasing intensity) from the Middle Turonian onward, deposition was influenced by synsedimentary activity of the Lausitz Thrust Fault (Voigt 1994, 2009; see Kley \& Voigt 2008 for further information on Late Cretaceous inversion in Central Europe). Nevertheless, careful sequence stratigraphic analyses by Janetschke \& Wilmsen (2014) documented the preponderance of eustatic over tectonic signals for the Cenomanian and Turonian ages. Overviews on the geology of the Cretaceous in Saxony are provided by Tröger $(2003,2008)$, Voigt (2007) and Wilmsen \& Niebuhr (2014).

\section{Material and methods}

The sections have been logged in detail bed-by-bed and sedimentary fabrics have been at first hand classified by hand-lens. Characteristic lithofacies have been sampled for the preparation of thin-sections ( 25 specimens). Microfacies analysis has been conducted using a transmitting-light microscope (Leica M125) and carbonate rocks have been classified using the Dunham (1962) terminology. For calcareous siltstones to silty marlstones, the local name "Pläner" is used. This descriptive lithofacies term 

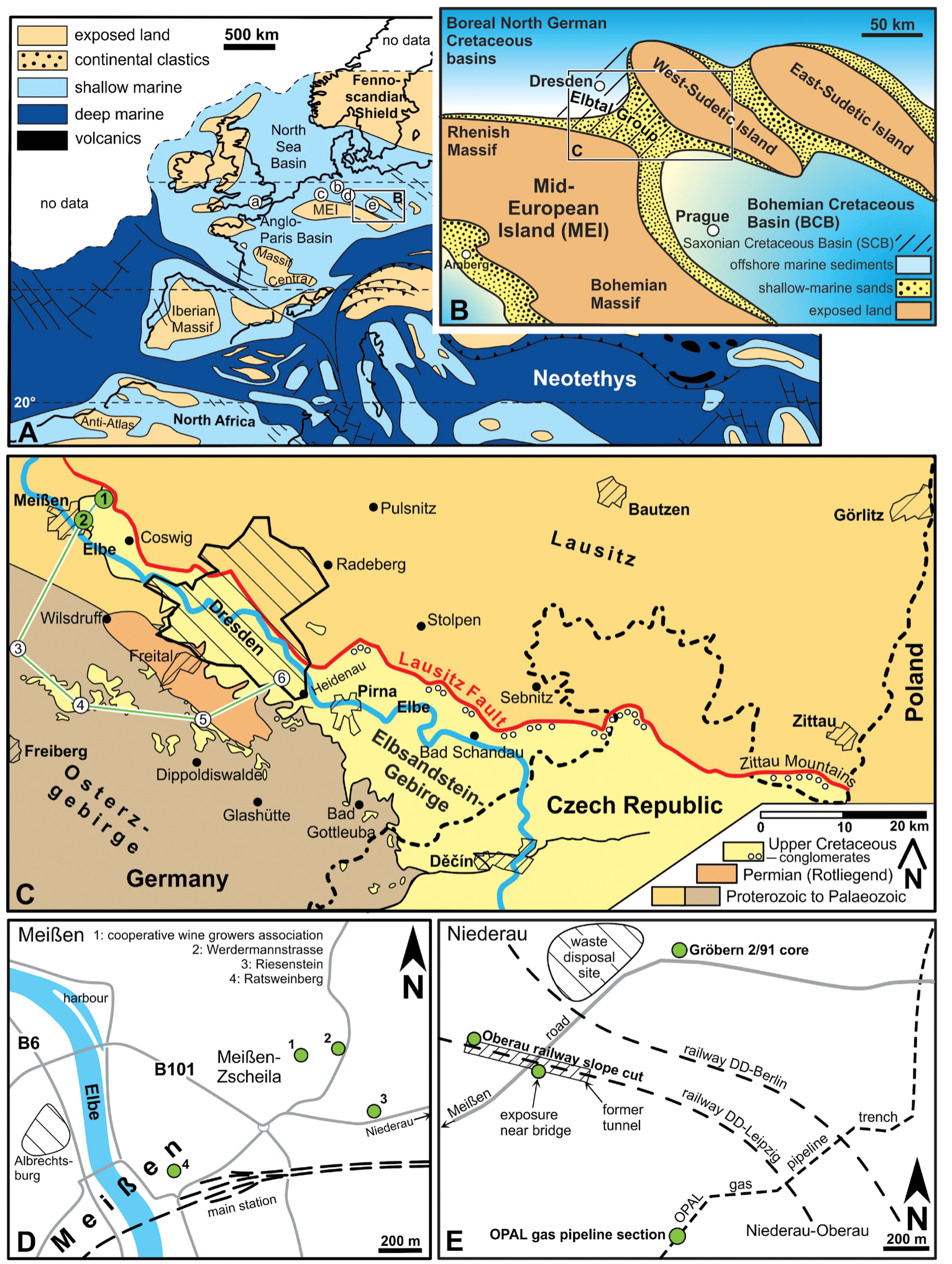

Figure 1. Geological and regional framework. $•$ A - Cenomanian palaeogeography of the western Tethyan area (modified after Philip \& Floquet 2000). The map area of Fig. 1B is indicated by a rectangle; small encircled letters a-e refer to the sections of the chemostratigraphic correlation (see Fig. 11). B - detailed palaeogeography of the Saxo-Bohemian area during the early Late Cretaceous with indication of the depositional setting of the Elbtal Group within the Saxonian Cretaceous Basin (the map area of Fig 1C is outlined). $\bullet$ C - distribution of the Elbtal Group along the Elbe river valley in Saxony ( 1 - Niederau area with Oberau and Gröbern, see Fig. 1E; 2 - Meißen, see Fig. 1D). The transect of Fig. 12 with the additional locations 3-6 is indicated. $\cdot \mathrm{D}$ - location of the sections studied in Meißen. $\cdot \mathrm{E}-$ location of the sections studied in the Niederau area. 


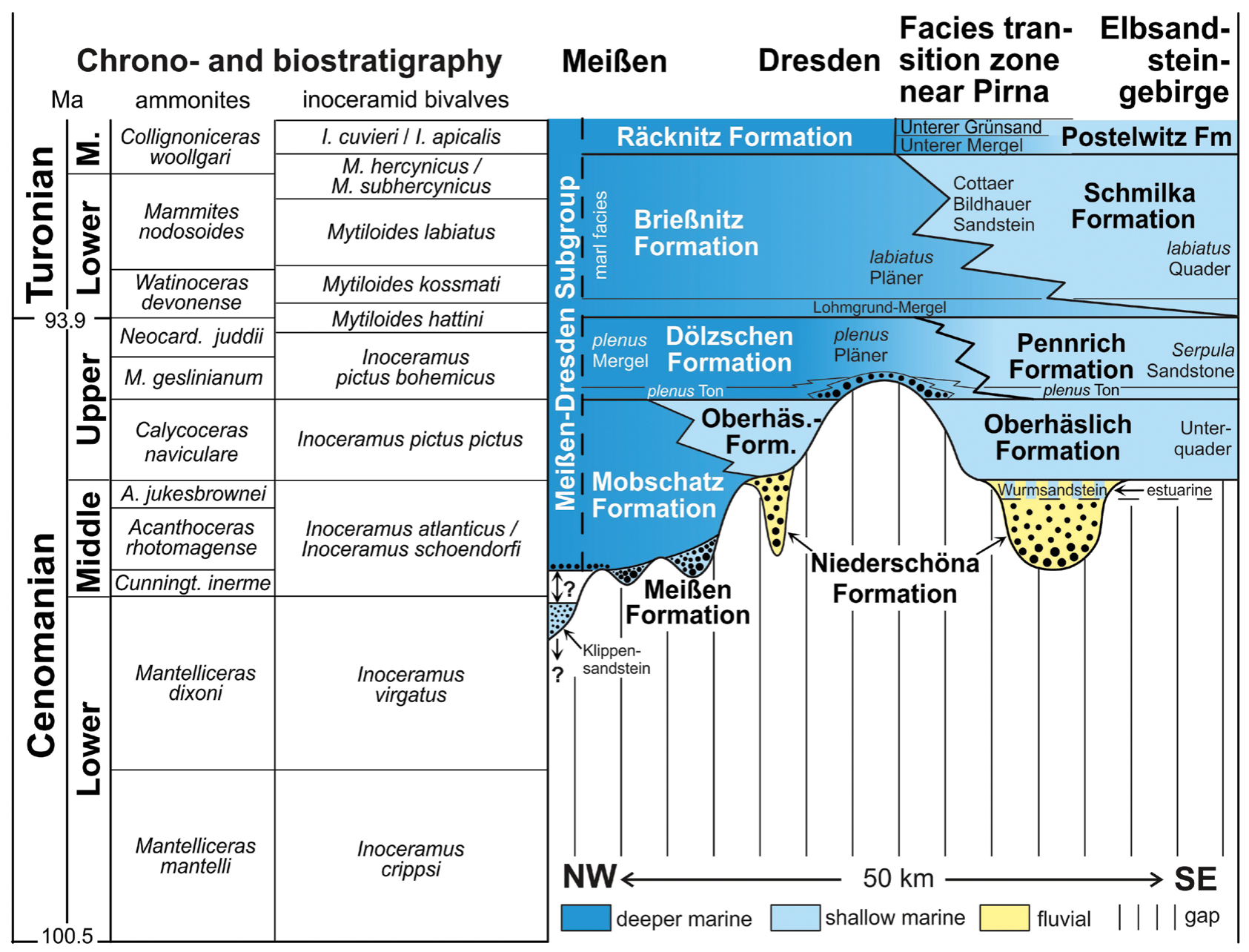

Figure 2. Schematic NW-SE section, following the River Elbe between Meißen and Bad Schandau, illustrating the litho- and biostratigraphy of the lower Elbtal Group (without Zittau Mountains, cf. Fig. 1C) as understood herein. Abbreviations: Cunningt. - Cunningtoniceras; A. - Acanthoceras; M. - Metoicoceras; Neocard. - Neocardioceras; M. - Mytiloides; I. - Inoceramus.

is known since the $18^{\text {th }}$ century and has been used in the Dresden area originally for planar, evenly shaped ragstones (Gerber 1717, p. 568; Freiesleben 1836, p. 226). Observations on fabrics, trace- and body-fossil content as well as taphonomy have been integrated into the synoptic stratigraphic logs. Topographic elevations at Oberau have been measured with a GNSS (global navigation satellite system) RTK (real-time kinematic) rover and are reported with respect to the WGS84 ellipsoid (3D error $0.05 \mathrm{~m}$ ). The fossil specimens and thin-sections are housed in the Museum für Mineralogie und Geologie (MMG) of the Senckenberg Naturhistorische Sammlungen Dresden (repository abbreviation SaK). The Gröbern 2/91 core is stored in the Lithothek of the Technische Universität Bergakademie Freiberg.

In total 32 samples for carbon and oxygen stable isotopes have been collected from the Oberau sections and the lower part of the Gröbern 2/91 core, and were analysed at Erlangen University (isotope lab of GeoZentrum
Nordbayern). For stable isotope analyses, carbonate powders were reacted with $100 \%$ phosphoric acid at $70{ }^{\circ} \mathrm{C}$ using a Gasbench II connected to a ThermoFisher Delta V Plus mass spectrometer. All values are reported in \%o relative to V-PDB. Reproducibility and accuracy was monitored by replicate analysis of laboratory standards calibrated by assigning $\delta^{13} \mathrm{C}$ values of $+1.95 \%$ to NBS19 and $-46.6 \%$ to LSVEC and $\delta^{18} \mathrm{O}$ values of $-2.20 \%$ to NBS19 and $-23.2 \%$ to NBS18. Reproducibility for $\delta^{13} \mathrm{C}$ and $\delta^{18} \mathrm{O}$ was \pm 0.05 and \pm 0.05 ( 1 std. dev.), respectively.

A total of 22 samples (Gröbern - 13 samples; Oberau 5 samples; Meißen - 4 samples) were processed for calcareous nannofossil analysis by smear-slides, following the preparation technique given in Perch-Nielsen (1985). At least five traverses of each slide were screened under an Olympus BH-2 microscope at a magnification of 1000x. For biostratigraphy, the UC standard zonation for Upper Cretaceous calcareous nannofossils from Burnett (1998) is 

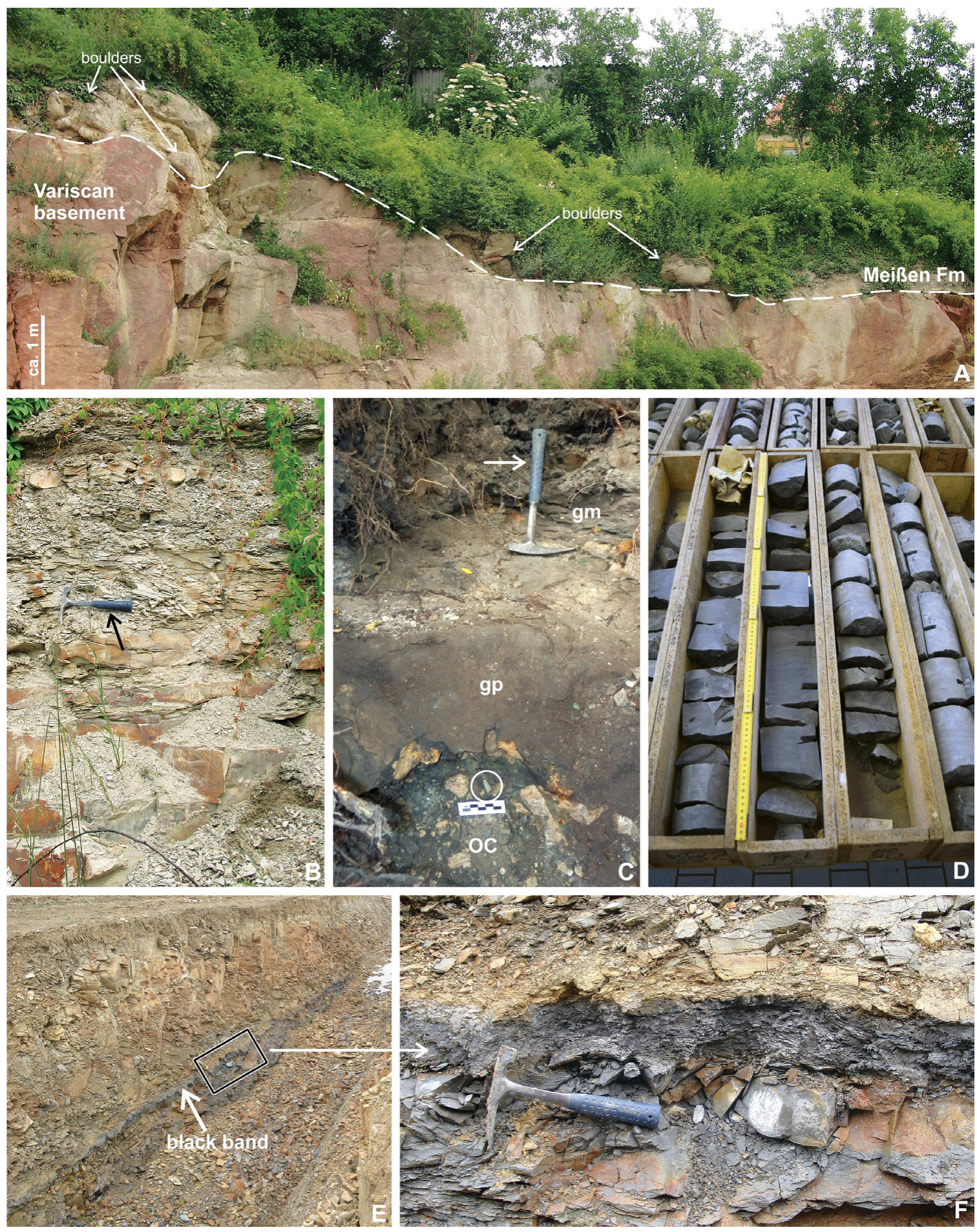

Figure 3. Field aspects of the studied sections. $\bullet A-$ the Meißen-Zscheila section at the cooperative wine-growers association (Winzergenossenschaft); note the irregular top surface of the basement (Meißen Massif, dashed line) and the large scattered boulders of the basal Meißen Fm. (arrowed). The Mobschatz Fm. rests immediately on the boulder level but is covered by vegetation. • B - exposure of marl and Pläner beds of the lower Dölzschen Fm. at Werdermannstraße in Meißen-Zscheila; hammer (arrowed, $28 \mathrm{~cm}$ in length) for scale. $\bullet \mathrm{C}-$ the Oberau railway slope cut exposure showing the basal conglomerate of the Mobschatz Fm. (Oberau Conglomerate, OC; the belemnite find illustrated in Fig. 8A, C is encircled) overlain by strongly glauconitic Pläner (gp) and glauconitic argillaceous marls (gm); hammer (arrowed, $33 \mathrm{~cm}$ in length) for scale. $\bullet \mathrm{D}-$ overview of the monotonous lithology of the Mobschatz Fm. in the Gröbern 2/91 core (core segments are $1 \mathrm{~m}$ long and $10 \mathrm{~cm}$ wide). E - OPAL gas pipeline trench (ca. $3 \mathrm{~m}$ deep) near Oberau in 2010 exposing argillaceous Pläner of the lower Dölzschen Fm.; note the black band (arrowed, $c a .15 \mathrm{~cm}$ thick, further details according to the rectangle in Fig. 3F). $• \mathrm{~F}$ - close-up of the black band (above hammer) in the lower Dölzschen Fm. of the OPAL gas pipeline trench section near Oberau; hammer (arrowed, $28 \mathrm{~cm}$ in length) for scale. 
applied, which is based on first and last occurrences (FO's, LO's) of marker species. The taxonomic classification follows Burnett (1998) with minor modifications by Shamrock \& Watkins (2009) and the data compiled on the Nannotax 3 database (Young et al. 2018).

The preservation state of each nannofossil assemblage is assigned to five categories, based on observations from Roth (1978) and Thierstein (1980): B - barren (no nannofossils present); VP - very poor (resistant taxa clearly dominate the assemblages, coccoliths are fragmented, etched or overgrown); $\mathrm{P}$ - poor (resistant taxa dominate, coccoliths are commonly fragmented, etched or overgrown); $\mathrm{M}$ - moderate (delicate taxa are present but are commonly fragmented, etched or overgrown); $\mathrm{G}$ - good (delicate taxa are common and rarely fragmented, etched or overgrown).

The nannofossil abundances are estimated from smear slide observations with medium density of particles. The average abundance is described by three categories regarding the number of coccoliths per field of view: L - low ( $<5$ coccoliths); $\mathrm{M}-$ medium (5-15 coccoliths); $\mathrm{H}-$ high ( $>15$ coccoliths).

\section{Results}

In total, four sites and sections have been measured and investigated by means of integrated stratigraphy and facies analysis, i.e. the Meißen area, the Oberau railway slope cut, the Oberau gas pipeline trench section and the Gröbern 2/91 core (Figs 1D, E; 3). The sections are described in detail below, including data on litho-, bioand microfacies.

\section{Sections}

\section{Meißen}

In Meißen-Zscheila, the Cretaceous cover rocks on top of the reddish granodiorites of the Meißen Massif (Carboniferous in age) were exposed in several old quarries and during building work in the 1990s. Still available is the slope cut at the cooperative wine-growers association (Winzergenossenschaft) in the Joachimstalstraße (Fig. 1D) where the Meißen Formation is exposed, resting unconformably on the basement (Fig. 3A), overlain by the basal glaucony-rich marls of the Mobschatz Formation. The overlying marls and Pläner of the Dölzschen Formation are exposed at the Werdermannstraße, $200 \mathrm{~m}$ to the east, close to the branch of the Großenhainer Straße (Fig. 1D). Collection material mainly derives from old quarries and construction work in the Riesenstein area (Fig. 1D).
At the cooperative wine-growers association, the Meißen Formation rests along an irregular basal unconformity surface on basement rocks of the Meißen Massif (Figs 3A, 4A). Boulders up to $2 \mathrm{~m}$ in diameter are scattered at the contact and embedded into a sandy, violet-red, ferruginous-calcareous matrix, constituting the characteristic lithofacies of the "red conglomerate of Meißen" (Prescher \& Tröger 1989). The sediment between the coarse crystalline components is a bioclastic, quartz and feldspar granule-bearing micritic sandstone to sandy bioclastic float- to rudstone dyed by ferric iron content (Fig. 4B, C). The most common bioclasts include echinoid spines, bivalves, corals and bryozoans. The Meißen Formation is patchily distributed and disappears laterally onto elevations protruding from the crystalline basement (Fig. 4A). It is overlain by glaucony-rich sediments of the Mobschatz Formation which, in the latter situation, may rest directly on the basement. At the Winzergenossenschaft, the lower Mobschatz Formation is developed as glauconitite (glaucony grains $>50 \%$, Funk 1971; Fig. 4D). From this part, large brachiopods [Neoliothyrina biplicata (Sowerby)] have been collected. These brachiopods also occur concentrated in crevice infills at the base of the Mobschatz Formation where it onlaps the basement rocks directly (Figs 4A, 8O). The basal glauconitites grade upsection into less glauconitic marls and Pläner deposits; the section is continued $15 \mathrm{~m}$ higher up with strata of the lower Dölzschen Formation at Werdermannstraße (Figs 3B; 4). In the lower part, Pläner deposits prevail (Fig. 4E). Up-section, a conspicuous facies shift to marly facies is exposed, showing plankton-dominated wackestones with planktic foraminifera and calcified radiolarian; siliciclastic content is subordinate (Fig. 4F, G).

At Meißen-Ratsweinberg (Fig. 1D) in the urban district Niederfähre-Vorbrücke, a 1-m-thick greensand rests directly on the basement of the Meißen Massif, overlain by marls and Pläner (Reinisch 1928). The succession is not exposed anymore, but the glauconitic basal bed was very fossiliferous, also yielding numerous large terebratulids assigned to $N$. biplicata, some of which are now hosted in the collections of the MMG. A small piece of matrix from specimen MMG: SaK 84 has been forwarded to nannofossil analysis (sample M-R, see below).

\section{Oberau railway slope cut}

This exposure corresponds to the former Oberau railway tunnel section of the historic literature (e.g. Geinitz 1839, Schneider 1843, Petrascheck 1900, Siegert 1906, Gallwitz 1935). Constructed in 1837-1839, the Oberau Tunnel was the first standard-gauge railway tunnel on the European mainland with a length of $513 \mathrm{~m}$. However, due to the limited railway loading gauge and considerable frost/water damages since its construction, the roof of 


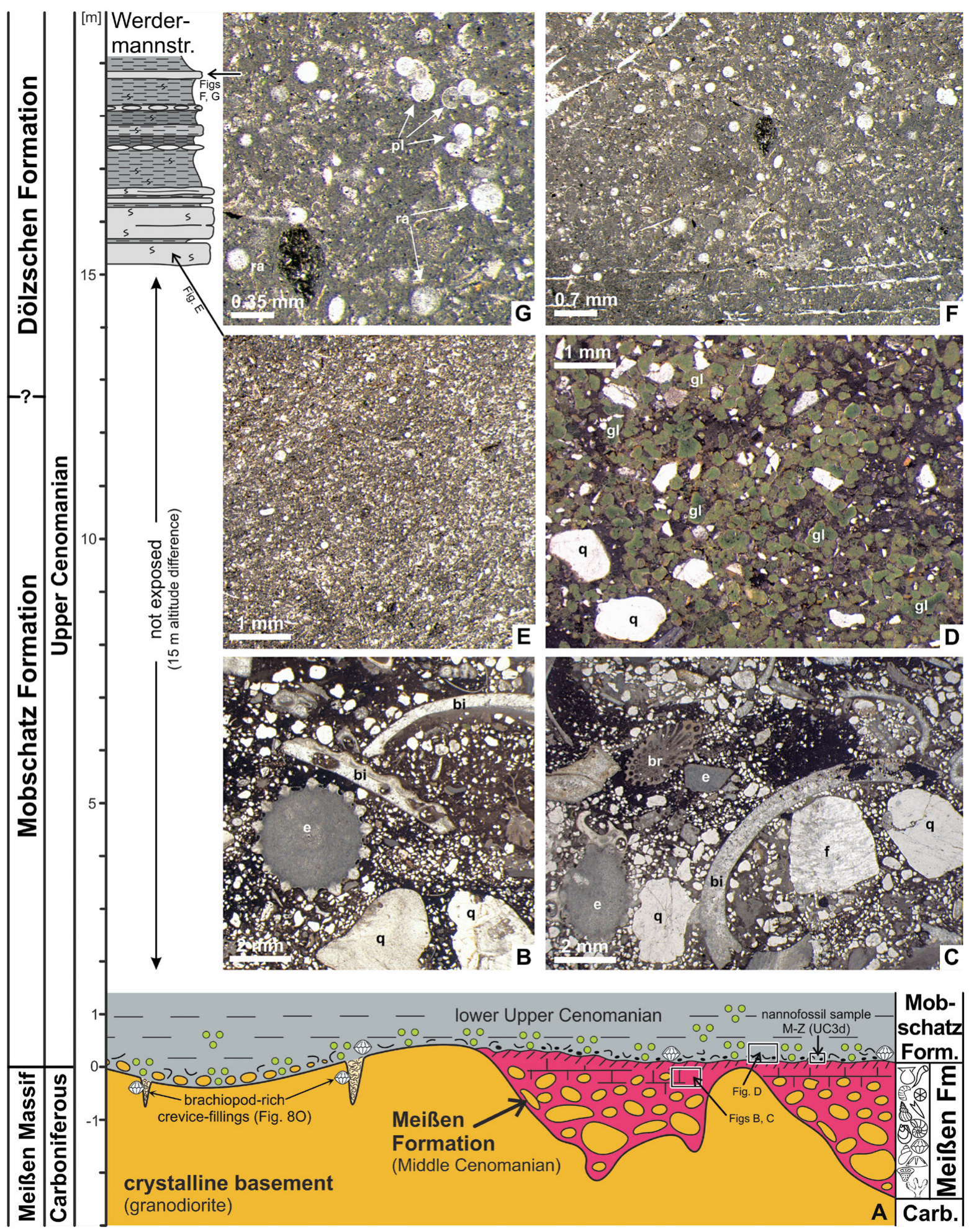

Figure 4. Geological situation at Meißen-Zscheila (key to symbols in Fig. 7; Carb. - Carboniferous; Form./Fm - Formation). • A - stratigraphic arrangement of the Meißen and Mobschatz formations based on Prescher \& Tröger (1989) and own observations; the sample position of images B-G are indicated. $\cdot \mathrm{B}, \mathrm{w} \mathrm{C}-$ microfacies of the Meißen Fm. in a sample taken between the coarse crystalline components showing immature bioclastic, quartz (q) and feldspar (f) granule-bearing sandstones to sandy bioclastic limestones with opaque ferruginous-micritic matrix; bioclasts include echinoid spines (e), bivalves (bi) and bryozoans (br). $\bullet \mathrm{D}$ - sandy glauconitite from the base of the Mobschatz Fm. (q = quarz, gl = glaucony). $\bullet \mathrm{E}-$ marly siltstone (Pläner) from the base of the section at Meißen-Werdermannstraße (lower Dölzschen Fm.). $\bullet \mathrm{G}, \mathrm{F}$ - calcareous marlstones from the upper part of the section at MeißenWerdermannstraße showing plankton-dominated wacke- to packstones with planktic foraminifera (pl) and calcified radiolaria (ra) of the Dölzschen Fm. 
the railway tunnel was removed in 1933-1934, and it was transformed into a railway cutting (Fig. 1E; see Preuß 1985). Most of the section is now overgrown but the general stratigraphic situation has been documented by Dietze (1961). Furthermore, the basal contact of the Mobschatz Formation with the underlying basement rocks is still fairly well exposed (Fig. 3C) and the stratigraphic relationships can still be evaluated at the northeastern railway slope cut.

Across a length of $c a .30 \mathrm{~m}$, a NW-SE-oriented transect on the northeastern slope cut exposes a complex stratigraphic architecture with conspicuous local onlap patterns (Fig. 5A). A small patch of bioclastic sandstones occurs in the southeastern part, corresponding to the "Schicht b" and the "Klippensandstein" of the literature (e.g. Geinitz 1839, Schander 1923, Dietze 1961) and representing the lowermost stratigraphic unit resting on the basement rocks. It consists of grey to beigecoloured, well-sorted, fine-grained quartz sandstones with numerous, part-silicified shells; granules of quartz and feldspar are scattered within the sandy-bioclastic fabric (Figs 5B, 6A). Intercalated, cm-thick sharpbased, granule-sized microconglomerate layers contain abundant angular feldspar grains and bioclasts, and show normal grading into the fine-grained sandstone facies. In part, they truncate sand-filled Ophiomorpha burrows and/or are penetrated by them. The macrofauna consists predominantly of bivalves (limids, pectinids, trigoniids and oysters) as well as gastropods, brachiopods, bryozoans and echinoderm remains. Sandstone slab MMG: SaK 172 contains a fragmentary internal mould of Schloenbachia varians (Sowerby) and another fragment has been collected during field work. The Klippensandstein is erosionally overlain by the basal conglomerate of the Mobschatz Formation (Oberau Conglomerate) that onlaps northwest-ward onto a local high in the basement (Fig. 5A). The sharp, irregular surface suggests that the Klippensandstein was already lithified (Fig. 6B).

The Oberau Conglomerate is of variable thickness and consists of angular to subrounded pebbles and cobbles derived from the basement rocks of the Meißen Massif in a strongly glauconitic, sand- and marl-rich matrix (Figs 5C; 6C, D). From the conglomerate, belemnites, terebratulid and rhynchonellid brachiopods, bivalves (including inoceramids and oysters), gastropods (pleurotomariids, naticids and nerineids), serpulids, small solitary corals and vertebrate remains have been recorded; the large brachiopods are a characteristic feature of its upper part. The $c a$. 0.75 -m-thick Oberau Conglomerate corresponds to beds ' $a$ ' and 'c' of Geinitz (1839) and grades into quartz-bearing marly glauconitites with conspicuously zoned glaucony grains and glauconitic marls that continue the onlap of the Mobschatz Formation onto the basement (Figs 3C, 4A; bed 'd' of Geinitz 1839).
Up-section, poorly exposed, medium-grey Pläner deposits continue the succession at the slopes of the railway trench (bed 'e' of Geinitz 1839). Approximately $300 \mathrm{~m}$ towards the east-southeast, marly Pläner are exposed at the southern side of the road bridge crossing the railway trench (Fig. 1E), yielding Inoceramus pictus bohemicus Leonhard (MMG: SaK 16242) and Euomphaloceras septemseriatum (Craigin). According to hypsometry, the topographic elevation is $151.4 \mathrm{~m}$ for the base of the Oberau Conglomerate and $164 \mathrm{~m}$ for the exposure at the bridge. Taking into account the distance of $300 \mathrm{~m}$ and the minor regional dip of the strata towards the east $\left(2-3^{\circ}, c f\right.$. Dietze 1961), the stratigraphic height between both levels is about $20 \mathrm{~m}$.

\section{Gröbern 2/91 core}

The Gröbern 2/91 core (Figs 1E, 3D, 7) was drilled in 1991 for subsurface investigation of a landfill site planned in this area. Overview $\operatorname{logs}$ with varying stratigraphic interpretations and initial low-resolution isotope data were provided by Tröger \& Voigt (1995), Tröger et al. (1996) and Voigt \& Tröger (1996), while Voigt et al. (2006) presented a detailed isotope stratigraphy as well as calcimetry and greyscale data of the Cenomanian-Turonian boundary interval. Additional microbiostratigraphic, ichnologic and geochemical data for this interval were provided by Ortmann (1994). However, the lower part of the succession, variably assigned to the Oberhäslich and/or Meißen formations, has never been studied in detail or precisely dated. Unfortunately, the lowermost metre of the core including the contact to the basement at $c a .70 \mathrm{~m}$ depth is not anymore available.

The preserved succession starts at a depth of $69 \mathrm{~m}$ below terrain surface (ground level elevation: $179.70 \mathrm{~m}$ ) with strongly glauconitic, silty to fine-sandy, bioturbated argillaceous marly Pläner of the lower Mobschatz Formation that contain scattered large quartz grains up to granule-size; fragments of brachiopods, oysters and siliceous sponges occur as biogenic components (Fig. $6 \mathrm{E}, \mathrm{F})$. The glaucony grains are zoned and the litho- and microfacies is very similar to the strata above the Oberau Conglomerate at the Oberau railway slope cut section (Fig. $5 \mathrm{~A}, \mathrm{C})$. Above, grain-size and glaucony content decrease up to the 63.80-m-level (Fig. 7). Between 63.80-57.40 m, bioturbated, glauconitic Pläner to silty-marly wackestones predominate in the middle part of the Mobschatz Formation (Figs 3D, 6G). Oblique spreiten structures referred to Zoophycos isp. filled with dark, argillaceous material are common in the Mobschatz Formation. At $57.40 \mathrm{~m}$, a conspicuous lithofacies shift to argillaceous Pläner deposits in the upper part of the Mobschatz Formation is evident (Fig. 7); within these marly strata, the planktic foraminifer Rotalipora cushmani has its first 
appearance at $54.50 \mathrm{~m}$ (Ortmann 1994). The Dölzschen Formation starts with a dm-thick conspicuous shell bed at $51.40 \mathrm{~m}$ depth, ranging up to the $32.50-\mathrm{m}$-level. It consists of an intercalation of calcareous and more argillaceous Pläner deposits with varying degree of bioturbation (Fig. 6H). Conspicuous marly intervals occur around $48 \mathrm{~m}$ (level of last occurrence of $R$. cushmani according to Ortmann 1994), between 45-40 m, between 38-36m and at $34.50-35 \mathrm{~m}$. At $c a .42 \mathrm{~m}$ depth, inoceramids of the I. pictus group occur and elements of the plenus or Pennrich faunas have been reported from the interval between 45-40 m (Tröger \& Voigt 1995, Voigt \& Tröger 1996, Tröger et al. 1996, Voigt et al. 2006). The base of a marly interval between $32.50-30 \mathrm{~m}$ (Lohmgrund-Mergel) has been used to place the base of the Brießnitz Formation. Above the Lohmgrund-Mergel, the unit is characterised

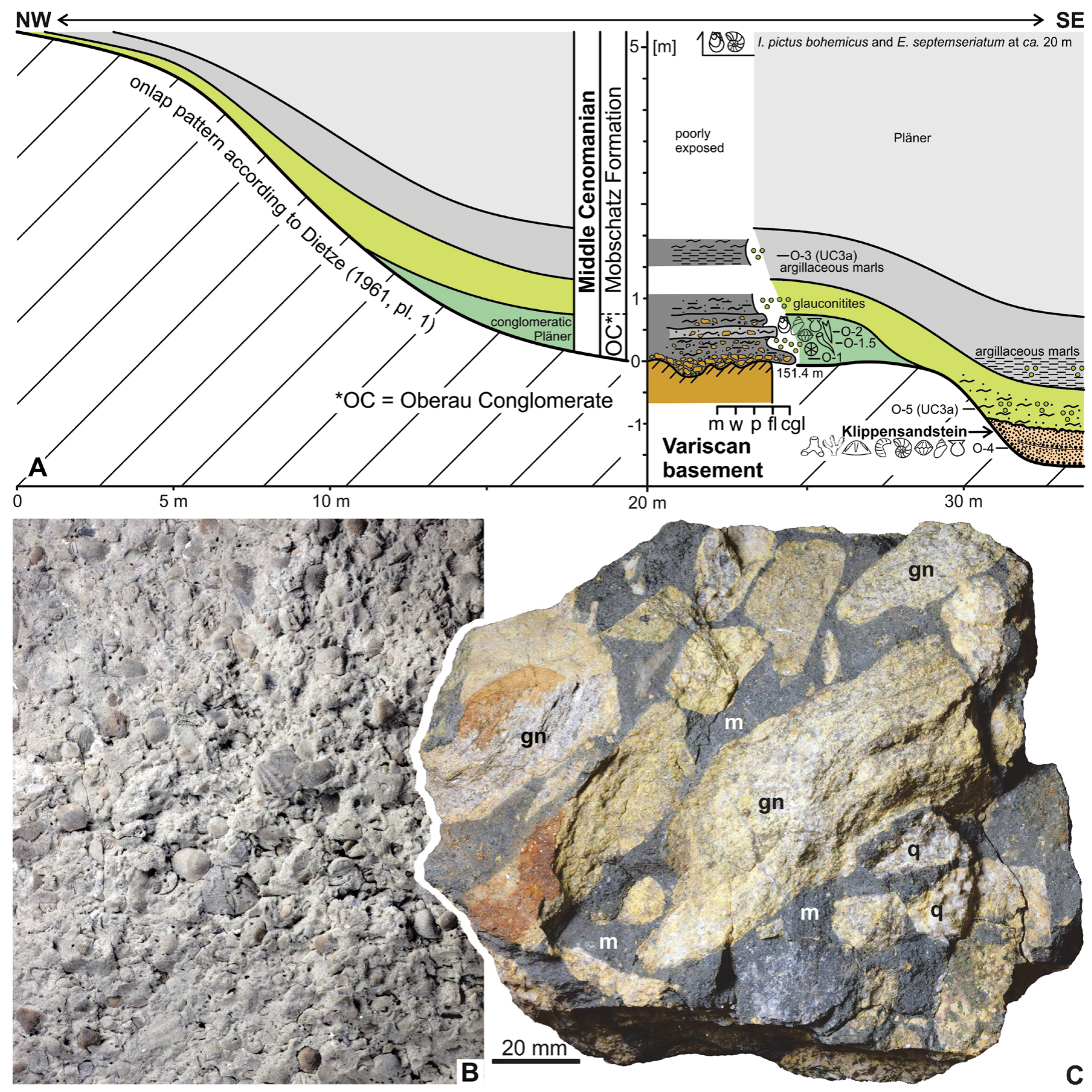

Figure 5. Geological interpretation of the Oberau railway slope cut (key to symbols in Fig. 7). $\bullet$ A - stratigraphic arrangement of lithofacies at the northeastern slope of the railway trench; note the NW-ward directed onlap patterns. $\bullet$ B - bedding surface from a slab of the Klippensandstein (sample MMG: SaK 7836, compare to Fig. 6A, B). Note the preferential convex-up position of the shells (mainly bivalves and brachiopods). $\bullet$ C - slab from the Oberau Conglomerate at the base of the Mobschatz Formation showing poorly sorted, angular to subrounded pebbles and small cobbles of basement rocks (gn - gneiss, q - milky quartz) in a dark, glaucony-rich matrix (m; compare to Fig. 6C, D). 
by an overall rise of carbonate content to around $70 \%$ (Voigt et al. 2006) and bioturbated microbioclastic wackestones with sponge spicules and small planktic foraminifers predominate (Fig. 6I). The monotonous lithofacies persists to the top of the core (Fig. 7).

\section{Oberau gas pipeline trench}

This temporary section has been accessible only in 2010 for a few weeks during the construction of the OPAL gas pipeline (Figs 1E; 3E, F; 7). It exposed a ca. $3.50 \mathrm{~m}$ thick succession from the lower part of the Dölzschen Formation in typical Pläner lithofacies. An interesting lithological feature of the exposure was a 0.20 -m-thick black argillaceous bed (black band) in the lower part of the section (Fig. 3F). Macrofossils were extremely rare and only indeterminate inoceramid remains have been found in the upper part of the section containing the black band. From stratigraphically a few metres above, several specimens of the belemnite Praeactinocamax plenus have been collected, associated by the serpulid Pyrgopolon ( $P$.) septemsulcata (Fig. 8E, N).

\section{Macrofossils}

The macrofauna from the Meißen-Niederau area has been treated in detail by Geinitz (1839), Dietze (1959, 1961), Prescher \& Tröger (1989), Löser $(1989,2014)$, Köhler (1988, 1991, 1993, 1996, 2001, 2004, 2012), Spaeth \& Köhler (1997) and Köhler \& Spaeth (1998). Thus, only some selected, stratigraphically important Cenomanian macrofossils from the investigated strata are treated herein (Fig. 8).

\section{Meißen Formation}

The Red Conglomerate is very fossiliferous with a diverse invertebrate fauna of inferred late Early Cenomanian age based on its inoceramids (I. ex gr. crippsi Mantell,
I. virgatus Schlüter; Fig. $8 \mathrm{~L}$ ), ammonites [Schloenbachia varians (Sowerby), Scaphites obliquus Sowerby and alleged Turrilites scheuchzerianus Bosc], and belemnites [Neohibolites ultimus (d'Orbigny)] (see Köhler 1988, 1991, 2001; Prescher \& Tröger 1989; Spaeth \& Köhler 1997; Köhler \& Spaeth 1998; Wilmsen \& Mosavinia 2011). The single turrilitid ammonite (Fig. 8M), however, in fact is a Middle Cenomanian T. costatus Lamarck. Furthermore, Sciponoceras cf. baculoides (Mantell) (Fig. 8J) has been found.

\section{Niederau (composite Oberau and Gröbern) section}

The Oberau Conglomerate of the basal Mobschatz Formation yields belemnites, brachiopods, inoceramid as well as non-inoceramid bivalves, gastropods, serpulids and small solitary corals. The common large, inflated terebratulid brachiopods with conspicuous growth lamellae and biplicate commissure are assigned to Neoliothyrina biplicata (Sowerby) (Fig. 8F), small forms with tuberculated radial ribs to Terebratulina nodulosa Etheridge (Fig. 8G). Large rhynchonellid forms with sharp radial ribs and round outline are representatives of the genus Cyclothyris M'Coy. The small solitary corals are Micrabacia coronula (Goldfuss), reported from Oberau also by Löser (2014). A moderately preserved inoceramid bivalve from the base of the section, assigned by Dietze (1959) to Inoceramus pictus bohemicus Leonhard, is re-identified as a Middle Cenomanian I. cf. atlanticus (Heinz) (Fig. 8H). The fragmentary belemnites, allocated to Belemnites lanceolatus Sowerby by Geinitz (1849) and Praeactinocamax plenus (Blainville) by Wilmsen (2014), are representatives of the genus Praeactinocamax Naidin, but, based on their fragmentary preservation, can only be identified at generic level (Fig. 8A-C). However, it needs to be pointed out that they tend to have rather slender rostra (see discussion below).

The marl and Pläner facies of the Mobschatz and Dölzschen formations is very poor in macrofossils.

Figure 6. Microfacies aspects of the Oberau railway slope cut (A-D) and Gröbern 2/91 core (E-I) sections (w - horizontal width of photomicrograph). A - Klippensandstein: well-sorted, fine-grained quartz sandstones with numerous, in part silicified shells (si) with beige-brown colour, predominantly of bivalves, echinoderms (ec), and scattered granules of quartz $(\mathrm{q})$ and feldspar ( $\mathrm{w}=14 \mathrm{~mm}$, sample $\mathrm{O} 4)$. $・ B$ - irregular erosional contact of the Klippensandstein (q - quartz, fs - feldspar) and the basal Oberau Conglomerate of the Mobschatz Formation (arrowed); note that the Klippensandstein was already lithified before the deposition of the Oberau Conglomerate $(\mathrm{w}=14 \mathrm{~mm}$, sample OK2). $\cdot \mathrm{C}-$ Oberau Conglomerate, basal Mobschatz Formation: angular pebbles of crystalline basement rocks ( $\mathrm{pb}$, mostly gneisses) with component-supported fabric within a dark, marly-sandy glauconitic matrix (ma) $(\mathrm{w}=25 \mathrm{~mm}$, sample O1). Note disintegrating gneiss pebble in the lower right (dis-gn). $\bullet \mathrm{D}$ - matrix of the Oberau Conglomerate, basal Mobschatz Formation: sandy glauconitite; note the zoned glaucony grain near centre (zg) and lobate shape of other green grains on left side (arrows; $\mathrm{w}=2.8 \mathrm{~mm}$, sample O1). E , F - lower part of the Mobschatz Formation: strongly glauconitic (green, partly zoned grains), silty to fine-sandy, bioturbated Pläner containing scattered larger quartz grains up to granule-size (q); biogenic components are fragments of brachiopods (br), oysters and siliceous sponges $(\mathrm{sp})(\mathrm{wE}=7 \mathrm{~mm}, \mathrm{wF}=14 \mathrm{~mm}$, samples $\mathrm{D} 1$ and $\mathrm{D} 2) \cdot \bullet \mathrm{G}-$ bioturbated, glauconitic silty wackestone (Pläner of the middle Mobschatz Formation, $\mathrm{w}=7 \mathrm{~mm}$, sample D3). $\bullet \mathrm{H}$ - bioturbated marly siltstone with oblique spreiten structure of Zoophycos isp. (arrowed) (Pläner of the lower Dölzschen Formation at $49 \mathrm{~m}, \mathrm{w}=7 \mathrm{~mm}$ ). $・ \mathrm{I}$ - bioturbated microbioclastic wackestone with sponge spicules and small planktic foraminifers (marl facies of the lower Brießnitz Formation, $\mathrm{w}=7 \mathrm{~mm}$, sample D5). 

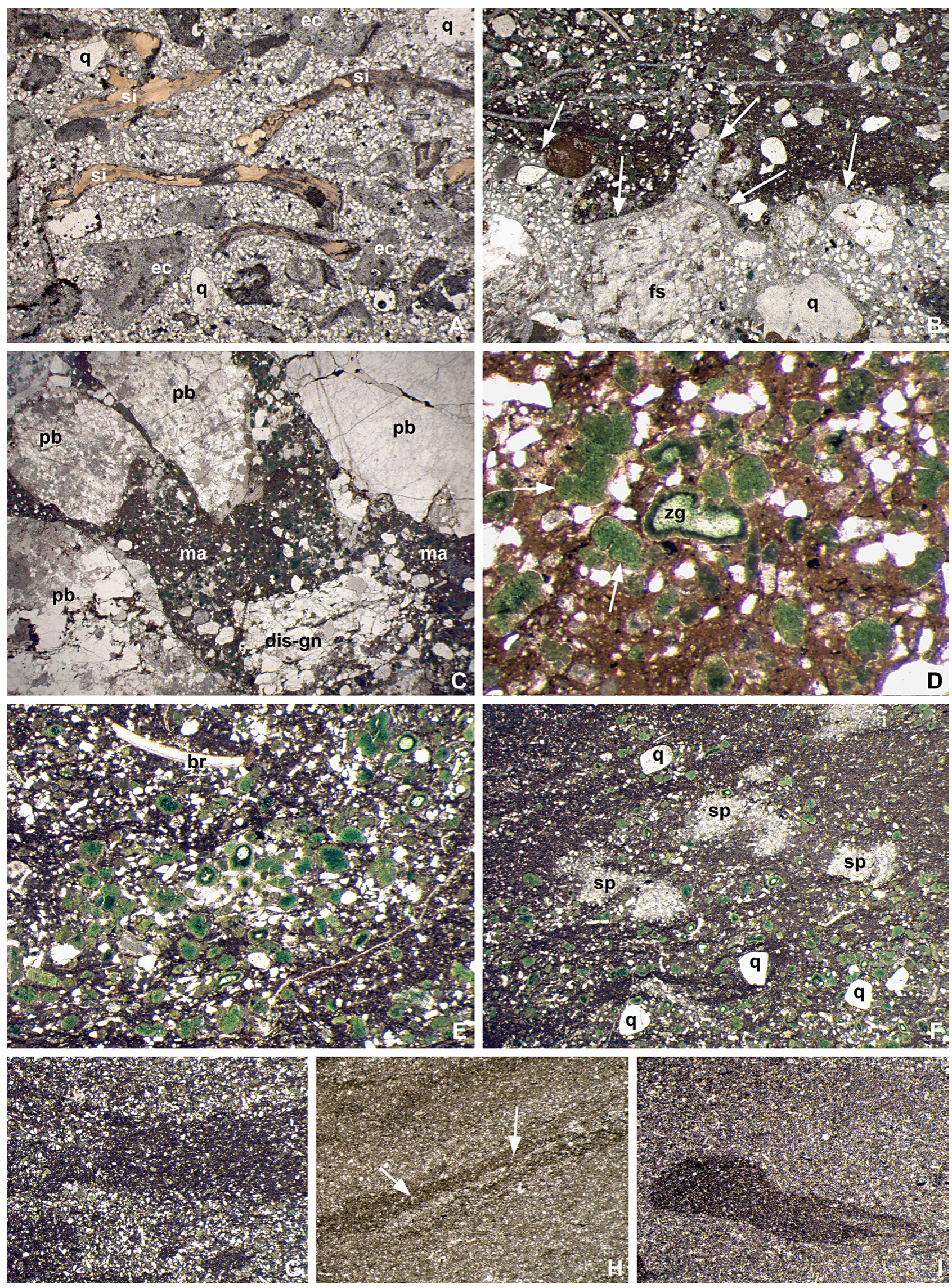
From the higher parts of the railway cutting at Oberau, different inoceramids of the pictus group and Mytiloides praeturonicus Tröger as well as Calycoceras naviculare (Mantell) (Fig. 8P), Sciponoceras gracile (Shumard) (Fig. 8K) and Praeactinocamax plenus were reported by Geinitz (1875), Dietze (1959, 1961), Wilmsen \& Nagm (2013, 2014) and Tröger (2015). Inoceramus pictus bohemicus Leonhard has been collected from the top of the Oberau railway slope cut section, $c a .20 \mathrm{~m}$ above the Oberau Conglomerate, where it co-occurs with the ammonite Euomphaloceras septemseriatum (Craigin); further M. geslinianum zonal ammonites (including the index species) and the belemnite Praeactinocamax plenus (Blainville), collected loose from the heaps of the tunnel slicing, have been reported by Köhler (1993, 2004, 2012). Inoceramus pictus bohemicus also occurs at the 42-m-level in the middle part of the Gröbern 2/91 core (Fig. 8I). From an interval not more than five metres above the black band in the OPAL gas pipeline trench near Oberau (Fig. 7), several specimens of $P$. plenus have been collected (Fig. 8E) which were accompanied by common Pyrgopolon (P.) septemsulcata (Roemer; Fig. 8N).

\section{Calcareous nannofossils}

In total, 22 samples have been analysed for calcareous nannofossil contents and biostratigraphic assignments. The results are summarised in Tab. 1 and important species are illustrated in Fig. 9 (for taxonomic information, see Appendix).

\section{Meißen}

Four samples from the Meißen area were investigated. The nannofossil preservation varies from moderate/good (samples $\mathrm{M}-\mathrm{Z}$ and $\mathrm{M}-\mathrm{R}$ ) to barren (samples RC-1 and RC-2); the two prospective samples show medium to high abundances with a species richness of 36 and 57 taxa, respectively (Tab. 1). In the sample from the glauconitic marl (M-Z) at the base of the Mobschatz Formation at Meißen-Zscheila (Fig. 4), a nannofossil assemblage of 57 different species is documented (Tab. 1). These species include Lithraphidites acutus (FO at the base of UC3a) and Corollithon kennedyi ( $\mathrm{LO}$ at the top of UC3d). The taxa Gartnerago theta (LO at the top of UC3a), Staurolithites gausorhethium (LO at the top of UC3b) and Gartnerago nanum (LO at the top of UC3c) are not present. The sample M-R from the basal greensand at Meißen-Ratsweinberg yields a nannofossil assemblage of 36 different species (Tab. 1) characterized by the presence of Lithraphidites acutus and the absence of C. striatus. Two samples (RC-1, RC-2) from the calcareous matrix of the Red Conglomerate of the Meißen Formation are barren of nannofossils.

\section{Oberau railway slope cut}

Five samples from the Oberau section were prepared for calcareous nannofossil analysis (see Fig. 7, lower part, and Tab. 1). Only two samples (O-5, O-3) contain low to moderately abundant assemblages of 33 and 52 different species (preservation poor to good) while samples O-1, O-2 and O-6 are barren. In both samples, Lithraphidites acutus (FO at the base of UC3a, lower Middle Cenomanian) is present. Sample O-3, which is stratigraphically located above sample O-5, contains Gartnerago theta (LO at the top of UC3a). The lowermost two samples from the Oberau Conglomerate and the uppermost sample are barren of nannofossils.

\section{Gröbern 2/91 core}

A total of 13 samples was investigated from the Gröbern 2/91 core (see Fig. 7). The nannofossil preservation is very poor to moderate with low to high abundances and a median species richness of 33 (min. 13, max. 44; Tab. 1). The samples Grö-6, Grö-11, Grö-15 and Grö-20 are characterized by the presence of Lithraphidites acutus (FO at the base of UC3a) in sample Grö-6 and Gartnerago theta (LO at the top of UC3a) in sample Grö-20 (Fig. 9). The following sample Grö-N3 shows an absence of Gartnerago theta with a presence of Corollithion kennedyi (LO at the top of UC3d) while Grö-N4 is characterized by the absence of Corollithion kennedyi and Cylindralithus biarcus (FO at the base of UC4a). Sample Grö-N5 is marked by the absence of Axopodorhabdus albianus (LO at the top of UC5a) and Quadrum intermedium and the presence of Helenea chiastia (LO at the base of UC6). The samples Grö-N7, Grö-N8 and Grö-N9 are characterised by a typical earliest Turonian nannofossil assemblage, evidenced by the absence of Helenea chiastia and Eprolithus moratus (FO at the base of UC6b). This assignment to the lowermost Turonian is supported

Figure 7. Stratigraphic logs of the Gröbern $2 / 91$ core (supplemented by the Oberau railway slope-cut section at the base) and the Oberau gas pipeline trench section including carbon stable isotope (black curves: this paper; blue curve: Voigt et al. 2006) and proposed correlation. Successive phases of the positive isotope excursion of the OAE 2 after Paul et al. (1999), carbonate content (in green) after Voigt et al. (2006), local first (FAD) and last appearance datum (LAD) of the planktic foraminifer Rotalipora cushmani (Morrow) according to Ortmann (1994). The key to symbols applies to all other line drawings. 


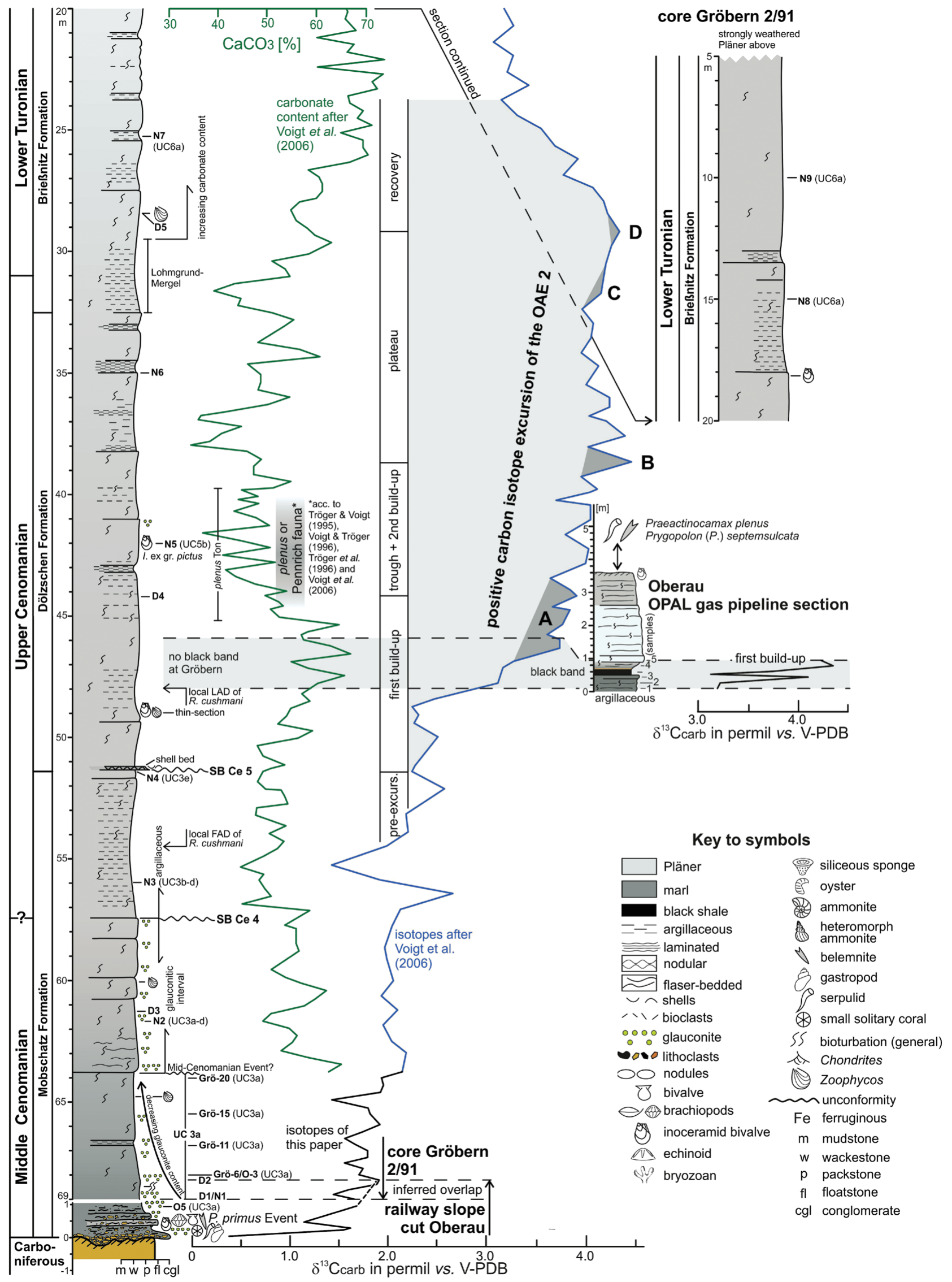


by the presence of Eprolithus octopetalus (FO at the base of UC5c, LO in UC8b; lower Turonian) in sample Grö-N9. In three samples (Grö-N1, Grö-N2, Grö-N6), a precise biostratigraphic zonation is undefined due to very poor preservation and the absence of marker species (Tab. 1)

\section{Isotopes}

The carbon stable isotopes from the railway slope cut at Oberau and the lower part of the Gröbern 2/91 core are supplemented by the data from Voigt et al. (2006) from the middle and upper part of the latter section. In combination, they form a continuous (Middle Cenomanian to lower Turonian) isotope record. Furthermore, the lower part of the OPAL gas pipeline section across the black band has been analysed.

The $\delta^{13} \mathrm{C}_{\text {carb }}$ values of the lower part of the Gröbern $2 / 91$ core vary between $1.44-1.94 \%$ and $\delta^{18} \mathrm{O}_{\text {carb }}$ values between -6.45 and $-7.99 \%$ while at the railway slope cut Oberau, $\delta^{13} \mathrm{C}$ values fluctuate between $0.38-1.88 \%$ for and -7.11 and $-11.27 \%$ for $\delta^{18} \mathrm{O}$. In the latter section, the carbon isotope values increase from the base of the Oberau Conglomerate ( $c a .0 .4 \%$ o $\delta^{13} \mathrm{C}$ ) across the glauconitites to almost $1.9 \% \delta^{13} \mathrm{C}$ in the argillaceous marls $\mathrm{ca} .2 \mathrm{~m}$ above (Fig. 7). The $\delta^{13} \mathrm{C}$ values at the base of the Gröbern $2 / 91$ core at $69-68 \mathrm{~m}$ are in the same order as at the top of the Oberau railway slope cut section (Fig. 7). They fluctuate between $1.5-2.0 \% \delta^{13} \mathrm{C}$ up to $63.80 \mathrm{~m}$ where they can be connected to the curve of Voigt et al. (2006) that continues the isotope record up-section. Up to the 57-m-level, $\delta^{13} \mathrm{C}$ values are relatively stable around $2 \%$, followed by a strong oscillation between 2.6 and $1.3 \% \delta^{13} \mathrm{C}$ in the interval $57-55 \mathrm{~m}$. Above, the curve shows some minor fluctuations between $2.25-2.50 \%$ o $\delta^{13} \mathrm{C}$ up to the 49 -m-level. From $49-24 \mathrm{~m}$ of the core, the major positive carbon stable isotope excursion of the oceanic anoxic event (OAE) 2 has been recorded, discussed in detail by Voigt et al. (2006) and Jarvis et al. (2011). The maximum value is $4.3 \%$ o $\delta^{13} \mathrm{C}$ at $38.50 \mathrm{~m}$.

At the OPAL gas pipeline trench, stable isotopes were only measured across the black band (Fig. 7). Values of $\delta^{13} \mathrm{C}_{\text {carb }}$ are ranging between $3.12-4.36 \%$ and show a conspicuous increase of $c a .1 .3 \%{ }^{13} \mathrm{C}$ from the base of the black band into the bed above.

\section{Discussion}

\section{Lithostratigraphy}

The composite succession of the Oberau railway slope cut and the Gröbern 2/91 core is very monotonous in terms of lithofacies and clearly reveals the limitations of the current lithostratigraphic framework of the Elbtal Group (cf. Voigt \& Tröger in Niebuhr et al. 2007, Fig. 3D) with respect to the distal facies zone (marl and Pläner facies of the Meißen-Dresden area). Without bio- or chemostratigraphic support it would be virtually impossible to differentiate the three formations (Mobschatz, Dölzschen and Brießnitz) comprised by the section. The problem will be even worse when it comes to field mapping for which formations as the basic and useful units of geological maps should be defined (e.g. Salvador 1994, Steininger \& Piller 1999). To provide a solution for this problem and to overcome potential mapping issues, we thus suggest to introduce the Meißen-Dresden Subgroup for the distal marl and Pläner facies of the Elbtal Group. The Meißen-Dresden Subgroup comprises

Figure 8. Selected macrofossils (natural sizes, except $\mathrm{G}$ which is $\times 2.5$ ). Lower Middle Cenomanian Oberau Conglomerate of the basal Mobschatz Formation at the Oberau railway slope cut section (A-C, F-H); upper Upper Cenomanian Dölzschen Formation (E, I, K, N, P); lower Middle Cenomanian Red Conglomerate of the Meißen Formation at Meißen-Zscheila (J, L, M); lower Upper Cenomanian Mobschatz Formation at Meißen-Zscheila (O). • A-C - Praeactinocamax sp.; A - find situation of the Praeactinocamax sp. illustrated in Fig. 8C; B - Praeactinocamax sp. (MMG: Sak 7807), original of Belemnites lanceolatus Sowerby in Geinitz (1849, pl. 6, fig. 5), alveolar end (B1), ventral view (B2), crosssection (B3); C - Praeactinocamax sp. (MMG: SaK 16378). • D - outline of the rostrum of Praeactinocamax primus (Arkhangelsky) from the lower Middle Cenomanian P. primus Event of Hoppenstedt (Wilmsen \& Rabe 2008) for comparison to a typical rostrum of P. plenus (Blainville). • E - Praeactinocamax plenus (Blainville) from the OPAL gas pipeline trench a few metres above the black band (mid-Upper Cenomanian P. plenus Event; Greif collection, Niederau). • F - Neoliothyrina biplicata (Sowerby) (MMG: SaK 16380). - G - Terebratulina nodulosa Etheridge (MMG: SaK 16379). • H - Inoceramus cf. atlanticus (Heinz) (specimen MMG: SaK 121), original of Inoceramus pictus bohemicus Leonhard in Dietze (1959, pl. 2, fig. 5). • I - Inoceramus pictus bohemicus Leonhard, Gröbern $2 / 91$ core at $42 \mathrm{~m}$ depth (specimen in the Lithothek, TU Bergakademie Freiberg). J - Sciponoceras cf. baculoides (Mantell), Köhler collection, Meißen; the arrow indicates a constriction. $\bullet$ K - Sciponoceras gracile (Shumard), MMG: SaK 4708 (lateral view) from the Oberau railway slope cut section; original of Baculites subbaculoides Gein. of Geinitz (1875a, pl. I.63, fig. 1). • L - Inoceramus virgatus Schlüter (specimen MMG: SaK73), original of Prescher \& Tröger (1989, pl. 28, fig. 5) and Tröger \& Niebuhr (2014, fig. 3d). • M - Turrilites costatus Lamarck, lateral view, original of Köhler (2001); Köhler collection, Meißen. • N - Pyrgopolon (P.) septemsulcata (Roemer) from the OPAL gas pipeline trench a few metres above the black band (mid-Upper Cenomanian P. plenus Event; Greif collection, Niederau). • $\mathrm{O}$ - crevice infill with large brachiopods at the base of the Mobschatz Formation at Riesenstein; Köhler collection, Meißen. • P - Calycoceras naviculare (Mantell) from the higher part of the Oberau railway slope cut section (specimen MMG: SaK 4706, P1 in lateral and P2 in ventral view), original of Wilmsen \& Nagm (2014, fig. 6d). 
Markus Wilmsen et al. - The Late Cretaceous transgression in Saxony

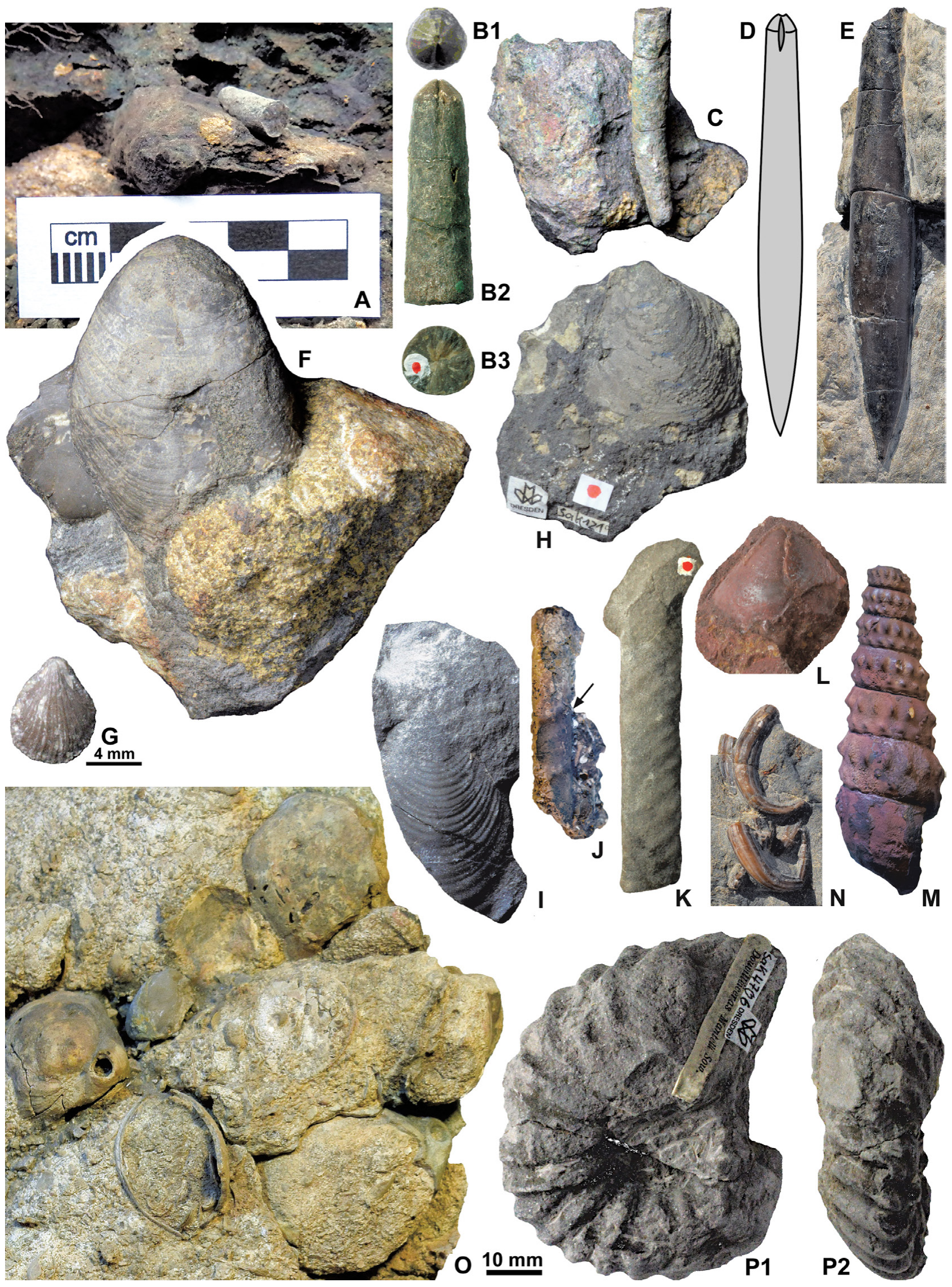


Table 1. Calcareous nannofossil data compiled from all studied samples. Preservation: $\mathrm{B}$ - barren; $\mathrm{VP}$ - very poor; $\mathrm{P}$ - poor; $\mathrm{M}$ - moderate; $\mathrm{G}$ - good. Nannofossil abundance: $\mathrm{L}=$ low; $\mathrm{M}$ - medium; $\mathrm{H}$ - high. Nannofossil taxa: $\odot-$ taxon present by single specimen; $\bullet-$ taxon present by at least two specimens.

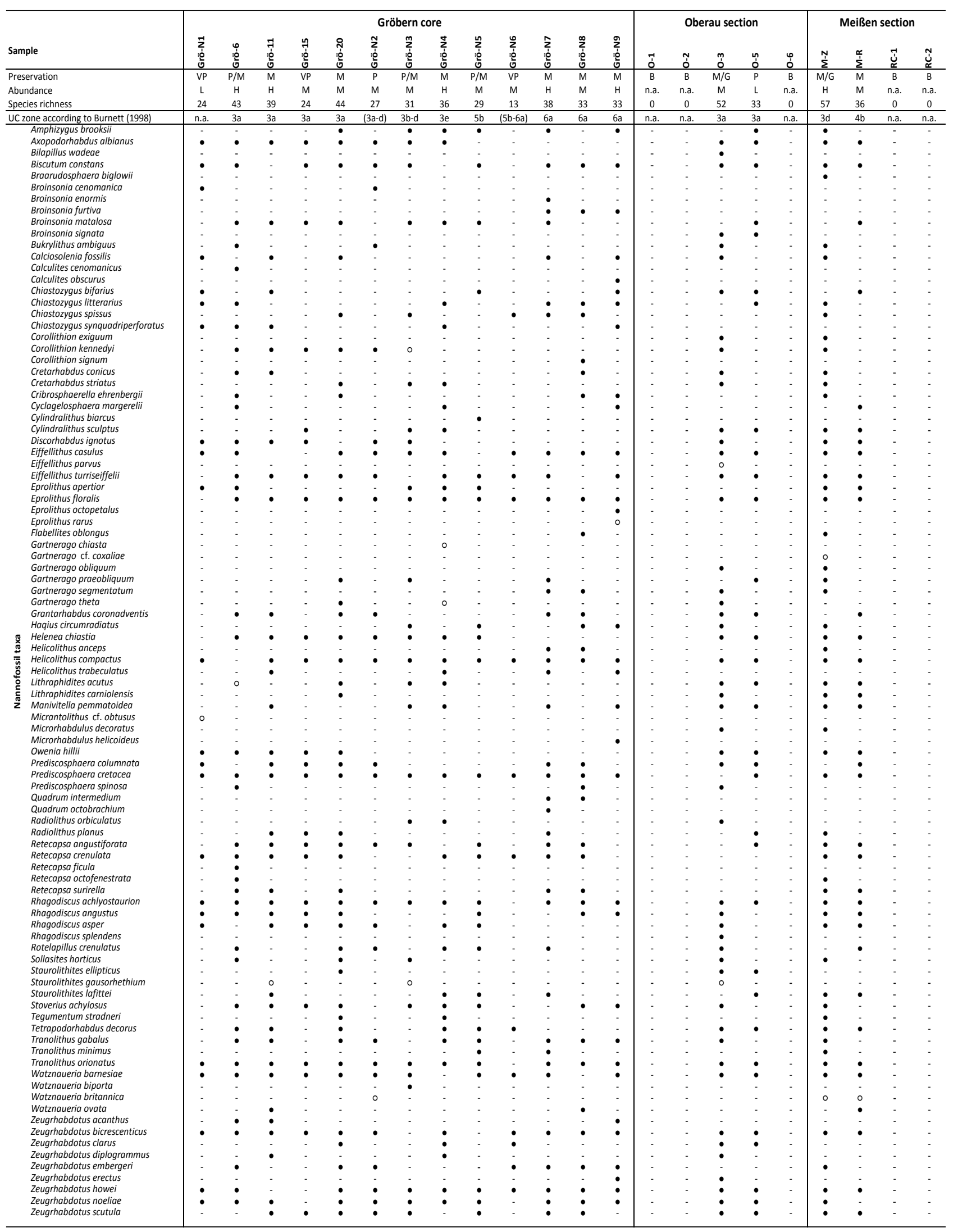




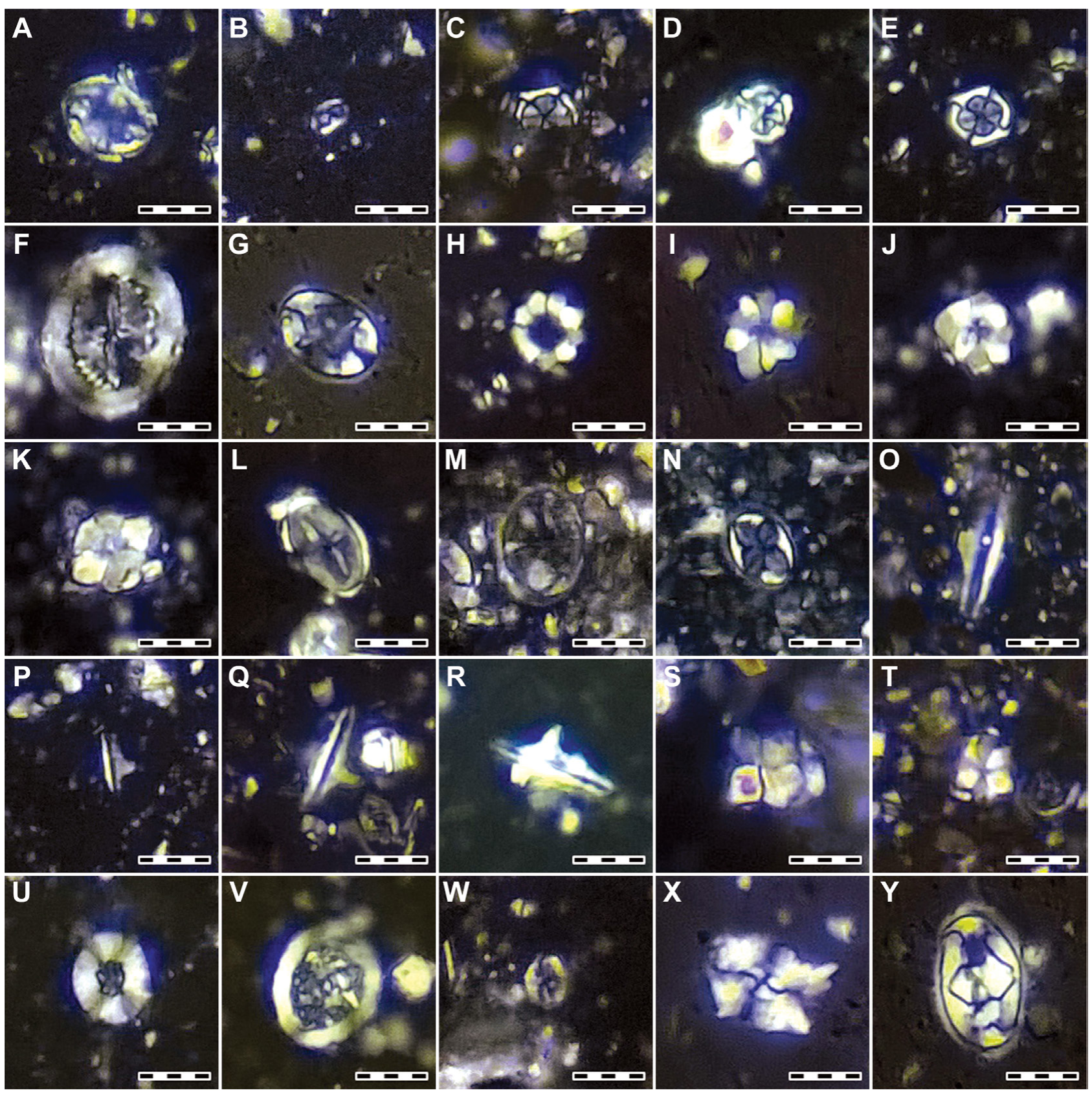

Figure 9. Light-microscopic photographs of diagnostic calcareous nannofossils from the Gröbern $2 / 91$ core, Oberau and Meißen sections (sample numbers in brackets; see Figs 4, 5 and 7 for precise stratigraphic levels). $・ \mathrm{~A}-$ Axopodorhabdus albianus (Oberau, O-3). $・ \mathrm{~B}-$ Bilapillus wadeae (Oberau, O-3). • C-E - Corollithion kennedyi; C - Gröbern, $56 \mathrm{~m}$; D - Meißen, M-Z; E - Oberau, O-3. • F - Cretarhabdus striatus (Oberau, O-3). • $\mathrm{G}-$ Eiffellithus turriseiffelii (Oberau, O-3). $\bullet \mathrm{H}-$ Eprolithus apertior (Meißen, M-Z). $・ \mathrm{I}-$ Eprolithus floralis (Meißen, M-Z). $・ \mathrm{~J}-$ Eprolithus octopetalus (Gröbern, Grö-N9). $・ \mathrm{~K}-$ Eprolithus rarus (Gröbern, Grö-N9). $・ \mathrm{~L}-$ Gartnerago segmentatum (Meißen, M-Z). $・ \mathrm{M}-$ Gartnerago theta (Gröbern, Grö-20). • N - Helicolithus compactus (Gröbern, Grö-N8). • O-R - Lithraphidites acutus; O - Gröbern, Grö-N3; P - Gröbern, Grö-6; $\mathrm{Q}$ - Oberau, O-3; R -Meißen, M-Z. • S - Quadrum intermedium (Gröbern, Grö-N7). $・ \mathrm{~T}$ - Quadrum octobrachium (Gröbern, Grö-N7). $・ \mathrm{U}-$ Retecapsa octofenestrata (Meißen, M-Z). $・ \mathrm{~V}-$ Rhagodiscus asper (Oberau, O-3). $・ \mathrm{~W}-$ Staurolithites gausorhethium (Gröbern, Grö-N3). $・ \mathrm{X}-$ Watznaueria barnesiae (Meißen, M-Z) with overgrown rim. $\bullet \mathrm{Y}-$ Zeugrhabdotus embergeri (Meißen, M-Z). Scale bar $=5 \mu \mathrm{m}$.

chronostratigraphically the Middle Cenomanian to Middle Coniacian and includes the Mobschatz, Dölzschen, Brießnitz, Räcknitz and Strehlen formations (modified according to Tröger \& Voigt in Niebuhr et al. 2007). When a subdivision in the field or a given section is impossible, the monotonous strata can eventually be grouped in this superordinate lithostratigraphic unit without need for further formational classification. 


\section{Biostratigraphy}

\section{Macrofossils}

The Meißen Formation is very fossiliferous, containing a diverse invertebrate fauna (e.g. Dietze 1961; Prescher \& Tröger 1989; Löser 1989, 2014). Based on its inoceramids (Inoceramus ex gr. crippsi, I. virgatus) and cephalopods (ammonites Schloenbachia varians, Scaphites obliquus and alleged Turrilites scheuchzerianus as well as the belemnite Neohibolites ultimus) it has been placed in the upper Lower Cenomanian (Prescher \& Tröger 1989; Köhler 1988, 1991, 2001; Spaeth \& Köhler 1997; Köhler $\&$ Spaeth 1998). However, none of these taxa is confined exclusively to the Lower Cenomanian (Fig. 10B): I. virgatus occurs in the upper Lower and lower Middle Cenomanian and also I. crippsi ranges from the lower Lower into the lower Middle Cenomanian (Tröger 2009; see also comment on I. ex gr. crippsi below). Schloenbachia varians appears in the Lower Cenomanian but persists into the lower Middle Cenomanian and occurs in the P. primus Event of northern Germany (Wilmsen et al. 2007; see also Wilmsen \& Mosavinia 2011 on the problem of "chronospecies" in Schloenbachia). Scaphites obliquus is a rather long-ranging (Lower-Middle) Cenomanian scaphitid ammonite (Wright \& Kennedy 1996).

A fragmentary rostrum of $N$. ultimus (d'Orbigny), reported by Spaeth \& Köhler (1997) and Köhler \& Spaeth (1998) from the Meißen Formation in MeißenZscheila, has also been used to support the early Cenomanian age of the deposit. However, as already shown by Combémorel et al. (1981), the species ranges into the lower Middle Cenomanian Turrilites costatus Subzone of the lower Acanthoceras rhotomagense Zone (see also Wilmsen 1999; Mitchell 2005). Furthermore, and most importantly, the alleged $T$. scheuchzerianus of Köhler (2001) is in fact a lower Middle Cenomanian T. costatus as clearly shown by the conspicuous tuberculation (Fig. 8M, T. scheuchzerianus has oblique ribs and no tubercles; see Wilmsen \& Nagm 2014 for details). This index taxon has its first appearance datum (FO) in the lower (but not lowermost) Middle Cenomanian, shortly below the $P$. primus Event, and characterises the lower part of the Acanthoceras rhotomagense Zone (see Wright \& Kennedy 2017 for a state-of-the-art synopsis of Cenomanian ammonite stratigraphy). Further support for a Middle Cenomanian age comes from the first report of Sciponoceras cf. baculoides (Mantell) from the Meißen Formation (Fig. 8J). The specimen is rather poorly preserved, but its oval cross-section, faint ventral ribbing and spaced oblique constrictions clearly separate it from lowermost Cenomanian $S$. roto Cieśliński. S. baculoides first appears in flood abundance at the top of the $T$. costatus Subzone of the A. rhotomagense Zone (Wright \& Kennedy 1995).
The $P$. primus Event, defined at the type locality of Wunstorf near Hannover (Ernst et al. 1983), is a conspicuous bioevent that formed in connection with a strong early Middle Cenomanian transgression (e.g. Gale 1995; Wilmsen 2003, 2007, 2012; Mitchell 2005; Wilmsen et al. 2007; Wilmsen \& Rabe 2008). Apart from the eponymous belemnite, Praeactinocamax primus (Arkhangelsky), a number of different invertebrates are typical elements of the so-called primus fauna (see Wilmsen et al. 2007 for a synopsis), most notably several small brachiopod, serpulid, coral and echinoid taxa such as Grasirhynchia grasiana (d'Orbigny) and Discoidea subucula (Leske) that are also known from the Meißen Formation (Prescher \& Tröger 1989).

In conclusion, the late Early Cenomanian age of the Meißen Formation is not biostratigraphically confirmed by the fauna, and the only reliable index fossil, i.e. T. costatus, rather suggests an early Middle Cenomanian age (as for the Oberau Conglomerate, see below). Furthermore, S. baculoides first appears at the top of the T. costatus Subzone so that all relevant macrofossils have their stratigraphic overlap in the lower A. rhotomagense Zone (Fig. 10B). Unfortunately, calcareous nannofossils and foraminifera cannot contribute to a further calibration of the age of the Meißen Formation (see below).

The ranges of biostratigraphically significant macrofossils of Oberau-Gröbern are shown in Fig. 10A. The inoceramid from the Oberau Conglomerate (Fig. $8 \mathrm{H}$ ) is of specific importance. In its subcircular outline, MMG: SaK 121 resembles the form figured as Inoceramus crippsi var. reachensis Eth. by Woods (1911, pl. 49, fig. 1), i.e. I. atlanticus (Heinz). However, its preservation is rather poor and it is thus kept in open nomenclature. Furthermore, very similar and probably conspecific inoceramids referred to as Inoceramus ex gr. crippsi have been reported from the $P$. primus Event at Wunstorf near Hannover (Wilmsen et al. 2007, fig. 6p) and the Totternhoe Stone of Burwell, Cambridgeshire (Woods 1911, p. 278), the stratigraphic equivalent of the $P$. primus Event in the Upper Cretaceous Transitional Province of England (see Wilmsen \& Wood 2004). It is well possible that the $I$. ex gr. crippsi reported from the Meißen Formation (Red Conglomerate) by Prescher \& Tröger (1989, not illustrated) also belong to this early Middle Cenomanian taxon. The belemnites from the Oberau Conglomerate have been hitherto regarded as Praeactinocamax plenus (Wilmsen 2014). This was, however, more of a "stratigraphic identification" because the Oberau Conglomerate has been regarded as the basal conglomerate of the Dölzschen Formation and placed in the upper Upper Cenomanian "Plenuszone" (i.e. the Metoicoceras geslinianum Zone; Schander 1923, Häntzschel 1933, Dietze 1961; only Petrascheck 1900 correlated the conglomeratic-glauconitic facies at Oberau with the lower Upper Cenomanian “Carinaten-Quader”, i.e. 


\section{A Niederau (Oberau and Gröbern)}

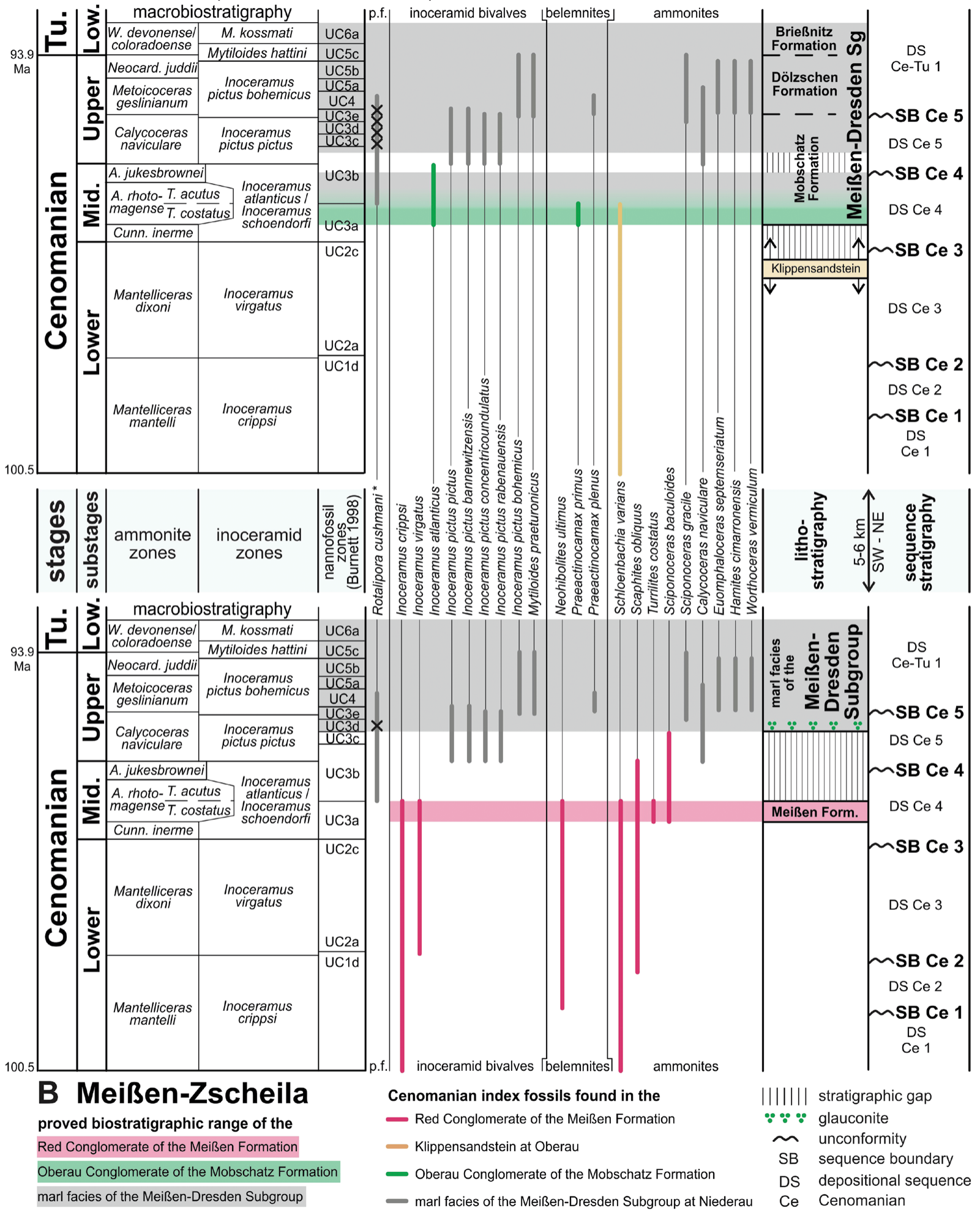

Figure 10. Biostratigraphic synopsis of the Cenomanian at A - Niederau (Oberau and Gröbern, above) and B - Meißen-Zscheila (below) based on index taxa recorded from the sections. The bars shown in the diagram correspond to the ranges for the taxa as reported in the literature (see text). * - occurrences of the planktic foraminifer Rotalipora cushmani (Morrow) according to Tröger $(1989,2003)$ and Ortmann (1994). Cenomanian standard sequence stratigraphy according to Robaszynski et al. (1998), Wilmsen (2003) and Janetschke et al. (2015). Abbreviations: A. - Acanthoceras; T. - Turrilites; Cunn. - Cunningtoniceras; Low. - Lower; M. - Mytiloides; Mid. - Middle; Neocard. - Neocardioceras: p.f. - planktic foraminifer; Tu. - Turonian; W. - Watinoceras. 
the Oberhäslich Formation). The stratigraphic view that the Oberau Conglomerate is the basal bed of the Dölzschen Formation in the area has been followed by all later authors (including Wilmsen \& Niebuhr 2014). However, the slender form of the rostra is not typical for P. plenus, which has a more club-shaped rostrum at (sub-) adult stage and grows larger, but is more typical of the closely allied earlier species $P$. primus (Arkhangelsky) (e.g. Christensen 1974, 1990; Košt’ák \& Pavliš 1997; Wiese et al. 2009; see Fig. 8D, E for comparison of adult rostra of the two species). The occurrence of the small brachiopod Terebratulina nodulosa, known from the Upper Albian to Cenomanian of England (Owen 1988), and the small solitary coral Micrabacia coronula support the early Middle Cenomanian dating of the Oberau Conglomerate as both are typical elements of the primus Fauna in northern Germany (Wilmsen et al. 2007). Calcareous nannofossils confirm the age assignment (see below).

Biostratigraphically significant macrofossils (ammonites, belemnites and inoceramid bivalves) from the middle and upper part of the Mobschatz and Dölzschen formations in the Niederau area have been discussed and/ or illustrated in various publications (Geinitz 1875; Dietze 1959, 1961; Köhler 1993, 2004, 2012; Wilmsen \& Nagm 2013, 2014; Tröger \& Niebuhr 2014; Tröger 2015). Albeit in some cases collected loose, the fauna clearly indicates the Upper Cenomanian C. naviculare and M. geslinianum zones (Figs 8, 10A).

\section{Calcareous nannofossils}

The calcareous nannofossil analysis documents an overall rare occurrence of marker species, e.g. Gartnerago theta, Staurolithites gausorhethium, Gartnerago nanum and Corollithion kennedyi (all taxa with LO's in UC3; Burnett 1998). Nevertheless, the observed nannofloral associations allow important biostratigraphic deductions (Tab. 1, Fig. 10).

The glauconitites of the basal Mobschatz Formation at Meißen-Zscheila can be assigned to an UC3d nannofossil zonal age (early Late Cenomanian; $c f$. Burnett 1998). This correlation was derived by a diverse nannofloral association including Corollithion kennedyi and Lithraphidites acutus and the absence of Gartnerago nanum (Tab. 1). However, at Meißen-Ratsweinberg, only $c a .1 \mathrm{~km}$ to the southwest of the Meißen-Zscheila sections (Fig. 1D), the presence of Lithraphidites acutus and the absence of $C$. striatus in the basal greensand that rests on the basement indicate the biozone UC4b (Burnett 1998). This demonstrates that the transgression occurred later here (mid-Upper Cenomanian M. geslinianum Zone) and that the strata are already part of the Dölzschen Formation.
From the Oberau-Gröbern composite section, a fairly consistent nannofossil biozonation emerged based on 15 prospective samples (Tab. 1). From the glauconitites directly above the Oberau Conglomerate, an early Middle Cenomanian age (UC3a) has been derived by the cooccurrence of L. acutus and Gartnerago theta, supporting the early Middle Cenomanian age of the conglomerate as inferred from macrofossils. UC3a continues up-section in the Gröbern 2/91 core up to the 64-m-level, defined by the presence of $G$. theta in the sample Grö-20. At $61.80 \mathrm{~m}$, an unspecified UC3a-d nannofloral association occurred (Middle to lower Upper Cenomanian). At $56 \mathrm{~m}$ and $51.5 \mathrm{~m}$, early Late and mid-Late Cenomanian ages result from calcareous nannofossil analyses (UC3b- $d$ and UC3e; Tab. 1) marked by the LO of C. kennedyi at $56 \mathrm{~m}$. Especially the latter datum is very important as it places the boundary between the Mobschatz and Dölzschen formations, as drawn herein, as well as sequence boundary SB Ce 5 at the junction of the Calycoceras naviculare and Metoicoceras geslinianum zones (cf. Burnett 1998; the $C$. naviculare Zone corresponds to the $C$. guerangeri Zone therein). The next sample at $42 \mathrm{~m}$ yielded an UC5b zonal age (late Late Cenomanian: upper M. geslinianum to lower Neocardioceras juddii zones); the UC4a-b and UC5a subzones have probably been missed due to the large inter-sample distance in this interval which is not in the focus of our study (the carbon stable isotope analysis of Voigt et al. 2006 provide a precise stratigraphic calibration of this part of the succession). Samples above $25 \mathrm{~m}$ consistently provided an Early (but not earliest) Turonian age (UC6a). The calcareous nannofossils thus show that the Oberau-Gröbern composite section covers the early Middle Cenomanian to Early Turonian.

\section{Foraminifers}

Foraminifers have not been studied herein, but existing data from Meißen are briefly evaluated herein. Fourteen benthic foraminifera were reported by Prescher \& Tröger (1989) from the Red Conglomerate of the Meißen Formation at Meißen-Zscheila. The assemblage contains many long-ranging species and is not very age-diagnostic, only the occurrence of Arenobulimina preslii indicates that the strata cannot be older than late Early Cenomanian M. dixoni Zone, and Berthelinia cenomanica limits the upper range to the Lower Turonian (foraminifer zones Ko-F2 to Ko-F5; see Dölling et al. 2014 for a recent synopsis on the Upper Cretaceous foraminifer zonation in northern Germany). From the lowermost part of the overlying Mobschatz Formation at Meißen-Zscheila, Tröger (1989) described an inferred Upper Cenomanian foraminifera fauna of predominantly benthic forms (22 taxa), again including $A$. preslii and $B$. cenomanica along with some planktic forms (unkeeled Muricohedbergella 


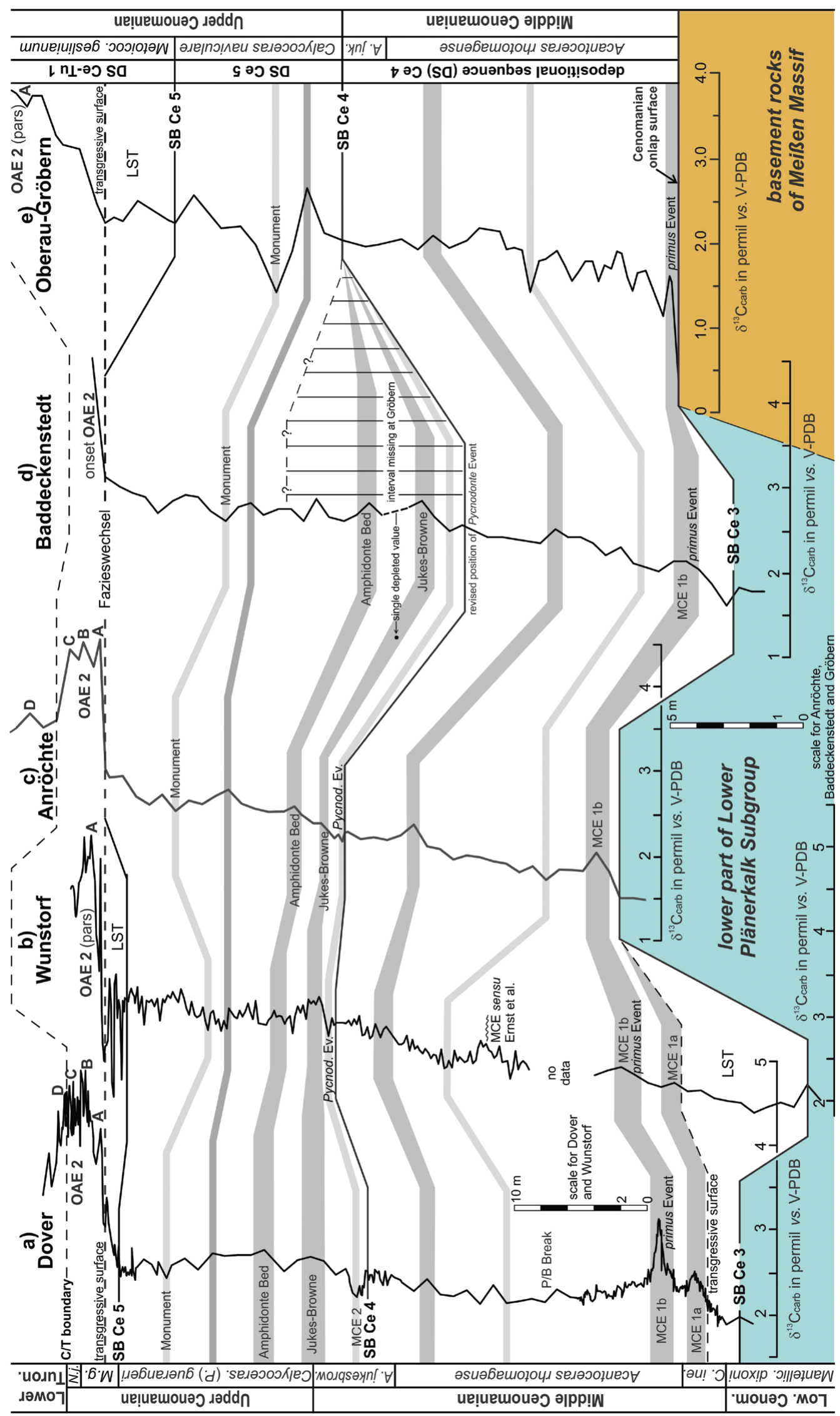

बீ

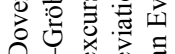

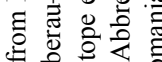

娄

엉

웅 영

究

总崩之

焉之卷 迅

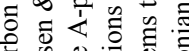

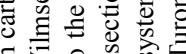

학요의

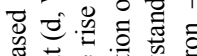

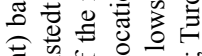

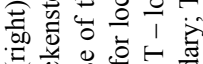

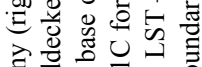

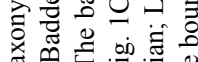

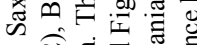

웡ㄹㄹㄹ

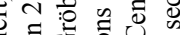

过

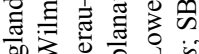

कo

者 考

言 券

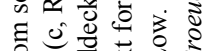

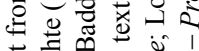

或:

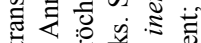

बी

$\exists$ 뭉

.

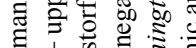

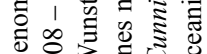

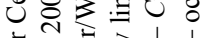

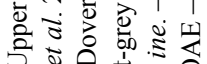

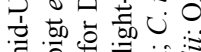

हैं क्ष

है

$\sum$ 远

의 연

눙웡 0

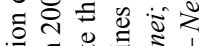

氜 $\overline{0}$

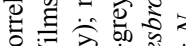

总音

क्वे

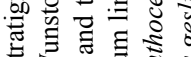

䗆言

웅 :

वृत क्ष

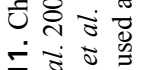

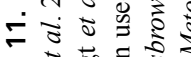

\% व.

舟 $>0$.

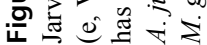


delrioensis and a keeled form loosely referred to "Globotruncana sp.", later assigned to Rotalipora cushmani by Tröger 2003, p. 3). Once more, this dating is rather poorly constrained by the benthic taxa identified but the presence of $R$. cushmani indicates the eponymous late Middle to mid-Late Cenomanian taxon range zone (e.g. Robaszynski \& Caron 1979a, b; Caron 1985). Nevertheless, a Late Cenomanian attribute of the fauna corresponds to the age assignment from the same layer based on calcareous nannofossils (UC3d, sample M-Z, see Fig. 4A and Tab. 1). The low planktic/benthic $(\mathrm{P} / \mathrm{B})$ foraminifera ratio $(c a .1 / 5)$ and the high percentage of agglutinating forms indicate relatively shallow-water conditions (Tröger 1989). From the Dölzschen Formation at the Ratsweinberg in Meißen Niederfähre-Vorbrücke (Fig. 1D), sixteen benthic foraminifer taxa have been reported by Rompf (1960), including A. preslii.

\section{Chemostratigraphy and sea-level changes}

The carbon stable isotope analysis of Voigt et al. (2006) provided a detailed stratigraphic dating and correlation of the middle and upper part of the Gröbern 2/91 core that contained a fairly expanded record of the major positive carbon stable isotope excursion of the oceanic anoxic event (OAE) 2 in the Cenomanian-Turonian boundary interval (Schlanger \& Jenkyns 1976, Schlanger et al. 1987). We thus focus on the hitherto poorly dated Middle to lower Upper Cenomanian part herein (Fig. 11). However, it should be noted that Jarvis et al. (2011) presented a chemostratigraphic reinterpretation of the Gröbern 2/91 curve, modifying some of the original results of Voigt et al. (2006) based on the correlation of isotope records from the Anglo-Paris and Vocontian basins. Jarvis et al. (2011, fig. 6) placed the onset of OAE 2 at $c a .51 \mathrm{~m}$ at the Gröbern 2/91 core, consistent with the interpretation herein (Fig. 7). This change from the preexcursion to the first build-up phase of OAE 2 (sensu Paul et al. 1999) coincides with the sub-plenus erosion surface in the Anglo-Paris Basin (Jeffries 1963), matching sequence boundary Cenomanian 5 ( $\mathrm{SB} \mathrm{Ce} 5$ ) at the junction of the $C$. guerangeri and $M$. geslinianum zones (Gale 1995, Robaszynski et al. 1998) and giving further support for the placement of this surface at the base of the conspicuous shell bed at $51.40 \mathrm{~m}$ at the Gröbern 2/91 core (Fig. 7). Originally, Voigt et al. (2006) correlated this sequence boundary (their $\mathrm{t}_{1}$ datum) to the $\sim 57-\mathrm{m}$-level at Gröbern. However, this lower surface cannot correspond to mid-Upper Cenomanian SB Ce 5, clearly shown by the early Late Cenomanian nannoflora from sample $\mathrm{N} 3$ at $56 \mathrm{~m}$, but matches SB Ce 4 in the Middle-Late Cenomanian boundary interval (see below). Finally, the Cenomanian-Turonian boundary (CTB) was inferred by
Voigt et al. (2006) in the interval between $30-26 \mathrm{~m}$ in Gröbern 2/91 core. Jarvis et al. (2011) calibrated the CTB to the $\sim 31.5-\mathrm{m}$-level and we placed it at $31 \mathrm{~m}$, within an argillaceous interval corresponding to the LohmgrundMergel, a marker bed at the base of the Brießnitz and Schmilka formations (Figs 2, 7).

The chemostratigraphic correlation of the Middle and lower Upper Cenomanian is based on an west-east transect of sections from southern England to Saxony, i.e. on Dover (Jarvis et al. 2006), Wunstorf near Hannover (Wilmsen 2007, Voigt et al. 2008), Anröchte in the Münsterland Cretaceous Basin (Richardt \& Wilmsen 2012), Baddeckenstedt in Lower Saxony (Wilmsen \& Niebuhr 2002) and the Oberau-Gröbern composite record (Voigt et al. 2006 and this study). It has to be stressed that the Oberau-Gröbern curve is not very detailed when compared to the high-resolution records of the expanded Dover and Wunstorf sections (Fig. 11). Nevertheless, the general increase in $\delta^{13} \mathrm{C}$ values from the lower Middle into the mid-Upper Cenomanian, up to the base of the OAE 2, is well reflected in the curve from Saxony and some contemporaneous isotope events (cf. Mitchell et al. 1996, Jarvis et al. 2006) can be identified with considerable confidence.

Deposition of Cenomanian strata started at OberauGröbern with the early Middle Cenomanian, a phase of major coastal onlap during the Cenomanian $2^{\text {nd }}-$ order sea-level rise (e.g. Gale 1995; Mitchell et al. 1996; Robaszynski et al. 1998; Wilmsen 2003, 2007; Wilmsen et al. 2007). This onlap phase consists of two pulses associated by two distinct positive isotope peaks of the Mid-Cenomanian Event (MCE) 1, i.e. MCE 1a (the arlesiensis Bed) and MCE $1 \mathrm{~b}$ (the P. primus Event; Gale 1995, Mitchell et al. 1996). The earlier pulse is commonly missing in proximal positions while the later $P$. primus Event transgression overlaps onto various basin margins (Wilmsen \& Niebuhr 2002, Wilmsen 2007, Wilmsen et al. 2007, Wilmsen \& Rabe 2008, Richardt \& Wilmsen 2012; Fig. 11). However, the isotope pattern of this interval is not identifiable in the low-resolution Oberau-Gröbern section and the onlap of the P. primus Event in the Oberau Conglomerate is only proved by biostratigraphic data and characteristic elements of the primus Fauna. Accepting the revised early Middle Cenomanian age of the Meißen Formation, the same transgression is recorded by the Red Conglomerate at Meißen-Zscheila. The Klippensandstein at the Oberau railway slope cut section records an earlier transgression but we cannot elucidate the precise stratigraphic position of this deposit; it either is a relic of a (late) Early Cenomanian transgression or records the first pulse of the early Middle Cenomanian transgression (i.e. the arlesiensis Transgression; Wilmsen 2007). The fact that the Klippensandstein already was lithified when the primus Transgression occurred favours the former 
interpretation. Some earlier authors (e.g. Geinitz 1839, Dietze 1961) regarded the Klippensandstein as a lateral facies equivalent of the Oberau Conglomerate but this appears rather unlikely given the completely different sedimentary fabrics of the two units and their unconformable contact.

The $P$. primus Event transgression created considerable accommodation space for deposition of Middle Cenomanian strata across the different basins (Fig. 11). The isotope patterns within depositional sequence DS $\mathrm{Ce} 4$ up to the capping uppermost Middle Cenomanian sequence boundary SB Ce 4 at the base of the Pycnodonte Event are characterised by a decrease of $\delta^{13} \mathrm{C}$ values above MCE 1 towards a minimum in the upper $A$. rhotomagense Zone, slightly above the P/B Break Event of Jarvis et al. (2006), followed by a faint increase towards SB Ce 4 split into roughly even segments by a central positive spike (Fig. 11). These isotope patterns can also be identified at Oberau-Gröbern up to the 57.50-m-level where $\mathrm{SB} \mathrm{Ce} 4$ has been placed (Figs 7, 11). Above SB Ce 4, a conspicuous sequence of negative (MCE 2; Mitchell et al. 1996) and positive isotope events (Jukes-Browne and Amphidonte Bed events; Jarvis et al. 2006) are readily identifiable and can be correlated confidently from Dover to Baddeckenstedt (Fig. 11). However, at Oberau-Gröbern, this striking isotope pattern is missing, suggesting that a considerable stratigraphic gap is present at the sequence boundary. It appears that the sea-level fall at SB Ce 4 resulted in a lack of accommodation at the Saxonian basin margin until transgressive strata of mid- $C$. naviculare zonal age onlapped the unconformity in the (late) transgressive systems tract of DS Ce 5 (Fig. 11). The conspicuous couplet of positive-negative peaks at Gröbern above SB Ce 4 is inferred to correspond to an unnamed spike and the Monument Event of Jarvis et al. (2006), respectively. Above the Monument Event, the German curves all show a bipartite rise in the upper $C$. naviculare Zone towards SB Ce 5 that terminates DS Ce 5 (Fig. 11).

The integrated stratigraphic analysis resulted in the following transgression history for the northwestern part of the Saxonian Cretaceous Basin (Fig. 12): the early Late Cretaceous transgression reached the Meißen-Niederau area in the early Middle Cenomanian and resulted in

Figure 12. Transgression history of the Cenomanian in Saxony $(1,2-$ Oberau-Gröbern and Meißen after this work, carbon stable isotopes after Voigt et al. 2006 and this work; 3 - Reinsberg-Dittmannsdorf after Tröger 2017; 4 - Tharandt Forest after Alexowsky et al. 2012 and Janetschke \& Wilmsen 2014; 5 - Bannewitz-Welschhufe after Janetschke \& Wilmsen 2014 and Wilmsen 2017; 6 - Dresden-Lockwitz after Wilmsen et al. 2011). See Fig 1C for course of the transect as well as Wilmsen \& Nagm (2013, 2014), Tröger \& Niebuhr (2014), Wilmsen (2014) and Tröger (2015) for data on ammonite, belemnite and inoceramid bivalve occurrences and biostratigraphy. Abbreviations: Dölzsch. - Dölzschen Formation; p. - pars; Turon. - Turonian.

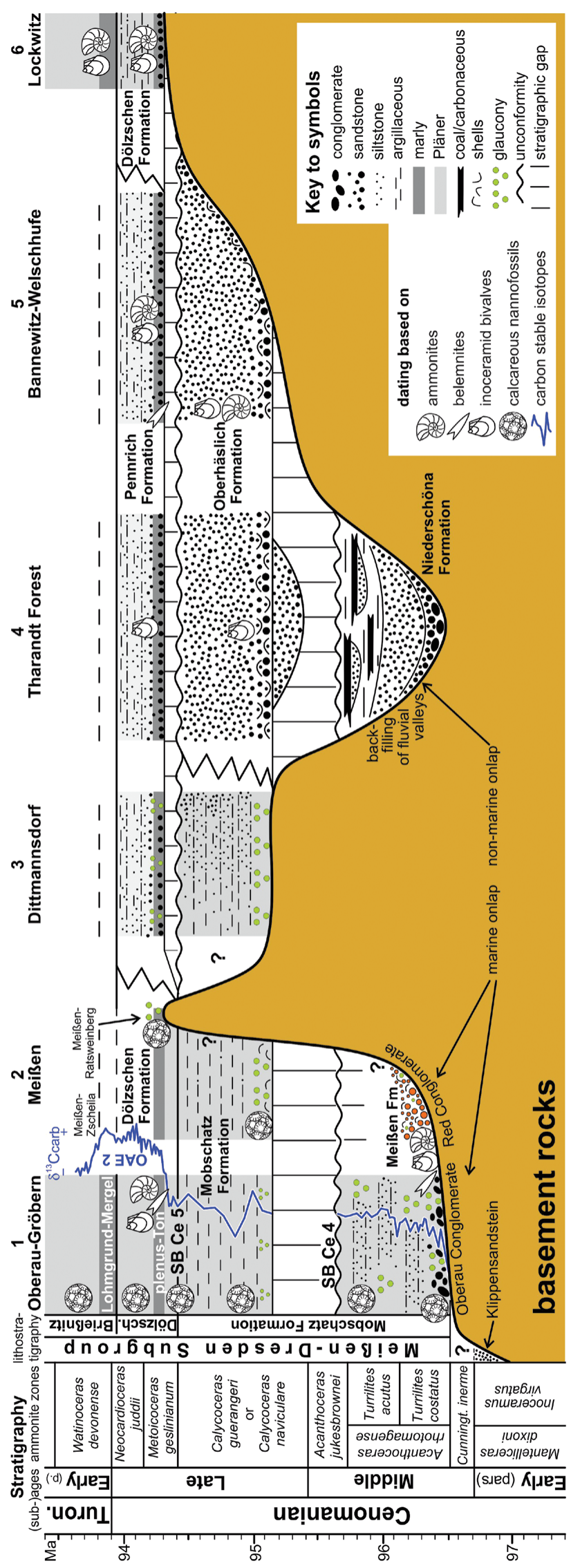


marine onlap of the lower Mobschatz and Meißen formations onto basement rocks of the Meißen Massif; the sea approached from the northwest and coastline was situated somewhere between Meißen and Dresden (see also Tröger 2017). However, also in the Meißen area, basement highs remained emergent (e.g. MeißenRatsweinberg), flanked by the high-energy facies of the Red Conglomerate (Fig. 12). The lack of significant sandy input during this time suggests that these basement highs were already disconnected from the mainland of the Mid-European Island and of rather small size, forming isles off the coast. Contemporaneous non-marine onlap is documented by the backfilling of fluvial valleys by the strata of the Niederschöna Formation (Voigt 1998) that shows the typical stratigraphic architecture and facies succession of a fluvial system during a base-level rise (Shanley \& McCabe 1993). A sea-level fall in the late Middle Cenomanian (SB Ce 4) terminated depositional sequence DS Ce 4 and resulted in a stratigraphic gap in the Middle-Upper Cenomanian boundary interval in the marine part of the basin and a conspicuous unconformity at the top of the Niederschöna Formation (Janetschke \& Wilmsen 2014).

The early Late Cenomanian naviculare Transgression caused a significant shift of the coastline towards the southeast and widespread marine onlap of the upper Mobschatz and Oberhäslich formations during DS Ce 5 (Fig. 12). A glauconitic transgression horizon characterises the basal Mobschatz Formation while coarsegrained, shell-rich siliciclastics predominate in the lower Oberhäslich Formation. Only some basement highs remained emergent during this phase of the early Late Cretaceous transgression (e.g. Tröger 1955, 2003, 2017; Voigt et al. 1994, 2006; Wilmsen et al. 2011). This also applies for the Meißen area as the nannofossil data show that the transgression occurred at Meißen-Ratsweinberg in $\mathrm{UC} 4 \mathrm{~b}$, i.e. not before the M. geslinianum Zone ( $c f$. Burnett 1998). A sea-level fall at SB Ce 5 at the boundary of the $C$. naviculare to $M$. geslinianum zones caused another stratigraphic gap in the proximal parts of the basin (lack of accommodation space) while in the distal Niederau area, the sea was deep enough to accommodate sediments also during falling and low sea-level of DS Ce-Tu 1 in the early geslinianum Zone (Fig. 12). The latest Cenomanian to earliest Turonian sea-level rise overlapped the remaining positive areas (including Meißen-Ratsweinberg), causing the onlap of the Dölzschen and Pennrich formations and a starvation of the distal Meißen-Niederau area (increasing carbonate contents and lack of silt- and sandsized siliciclastics).

The revised transgression history in Saxony has also significance for the drainage history of the Bohemian Cretaceous Basin because the inferred outflow of Cenomanian fluvial to estuarine systems in the northern, western and central parts occurred along the presentday Elbe Valley (Uličný et al. 2009; Peruc-Korycany Formation). Although exclusively fluvial Lower Cenomanian strata are known from the basal parts of infilled palaeovalleys in some areas, brackish and tidal influences appeared with their Cen 2 sequence in the lower Middle Cenomanian and became more significant through time, with a first maximum transgressive surface (mts) in the mid-A. rhotomagense Zone (Špičáková et al. 2014). The backfilling of palaeovalleys by fluvial to estuarine strata continued during the Middle to Late Cenomanian and the marine flooding culminated close to the CenomanianTuronian boundary (Uličný et al. 1993, 2009; Uličný \& Špičáková 1996; Špičáková et al. 2014).

\section{Conclusions}

The stratigraphy of the Meißen Formation and distal marl and Pläner facies (Mobschatz, Dölzschen and Brießnitz formations) in the Meißen and Niederau (Oberau-Gröbern) areas of the northwestern Saxonian Cretaceous Basin is revised with important implications for the transgression history of the early Late Cretaceous in Saxony. The study is based on sections in Meißen and Oberau-Gröbern and applies an integrated approach of bio- (macrofossils, calcareous nannofossils), chemo-, event and sequence stratigraphy accompanied by detailed facies analyses (litho-, bio- and microfacies).

A re-evaluation of the faunal content of the Meißen Formation (the Red Conglomerate) suggests that the unit is rather of early Middle (Acanthoceras rhotomagense Zone) than late Early Cenomanian age, being unconformably overlain by the lower Upper Cenomanian Mobschatz Formation, the base of which yielded an UC3d nannofloral assemblage. At Oberau (Niederau area), the transgressive Oberau Conglomerate at the base of the Mobschatz Formation, formerly regarded as the basal conglomerate of the Dölzschen Formation and placed in the mid-Upper Cenomanian M. geslinianum Zone, forms a contemporaneous equivalent of the Red Conglomerate. The macrofossil content of the bed demonstrates the older age and suggests that the contained belemnites are in fact Praeactinocamax primus that migrated to Saxony in connection with the early Middle Cenomanian primus transgression. Support for this interpretation comes from calcareous nannofossils which indicate the UC3a biozone for the strata immediately above the Oberau Conglomerate. Up-section, the Oberau section continues in the Gröbern 2/91 core and calcareous nannofossils show that the 70-m-thick Oberau-Gröbern composite section covers the Middle Cenomanian to Early Turonian (from the UC3a to UC6a biozones sensu Burnett 1998), supported by sporadic macrofossil occurrences. 
The stratigraphic dating and correlation is substantiated by new carbon stable isotope analyses from the lower part of the section that have been combined with published data from the middle and upper part of the succession that include the oceanic anoxic event (OAE) 2 in the Cenomanian-Turonian boundary interval. The Middle Cenomanian to lower Upper Cenomanian isotope curve has been correlated to records from the Anglo-Paris and northern German basins, suggesting a stratigraphic gap in the Middle-Late Cenomanian boundary interval in the middle part of Mobschatz Formation. This gap corresponds to a phase of falling and low sea-level stand connected to Cenomanian sequence boundary 4 ( $\mathrm{SB} \mathrm{Ce} 4$ ).

The transgression history continued in the early Late Cenomanian with the upper Mobschatz Formation at Oberau-Gröbern corresponding to the first onlap of the Mobschatz Formation onto the Meißen Formation and basement rocks at Meißen-Zscheila as well as on basement areas further in the southeast towards Dresden. Another sea-level fall is recorded by the formational contact of the Mobschatz and Dölzschen formations in the mid-Upper Cenomanian which can be tracked into a conspicuous unconformity in the proximal parts of the basin (SB Ce 5 at the boundary of the $C$. naviculare to $M$. geslinianum zones). The latest Cenomanian and earliest Turonian document a phase of major deepening characterised by submergence of the last basement highs as well as siliciclastic starvation and pelagic sedimentation in the Meißen-Niederau area.

The monotonous lithology of the composite Middle Cenomanian-Lower Turonian Oberau-Gröbern section clearly reveals the limitations of the current lithostratigraphic framework of the Elbtal Group with respect to the distal marl and Pläner facies zone, where formations can often only be differentiated by means of chronostratigraphic data. Thus, the introduction of the Middle Cenomanian to Middle Coniacian Meißen-Dresden Subgroup is suggested in which the lithologically uniform strata can be eventually grouped without the need for further formational classification.

\section{Acknowledgements}

We acknowledge constructive reviews by Ian Jarvis (London) and Radek Vodrážka (Prague) as well as the competent editorial handling by Jiří Laurin (Prague). Delia Rösel (TU Bergakademie Freiberg) is thanked for giving access to the Gröbern 2/91 core. Ronald Winkler (SNSD) prepared the thin-sections. We are also deeply indebted to the late K.-A. Tröger (Freiberg) for discussion of various stratigraphic aspects concerning the Elbtal Group. Martin Hiss (Krefeld) evaluated data on benthic foraminifera. Furthermore, we are indebted to S. Köhler (Meißen) and H. Greif (Niederau) for the possibilities to study their collections.

\section{References}

Alexowsky, W., Berger, H.J., Horna, F., Jaschke, I., Kurze, M., Renno, A., Stanek, K., Schneider, J.W. \& Tröger, K.-A. 2012. Geologische Karte des Freistaates Sachsen 1:25 000. Erläuterungen zu Blatt 5047 Freital. 3. Auflage. 180 pp. Sächsisches Landesamt für Umwelt und Geologie, Freiberg.

Burnett, J.A. 1998. Upper Cretaceous, 132-199. In Bown, P.R. (ed.) Calcareous Nannofossil Biostratigraphy. Chapman \& Hall, London.

CARon, M. 1985. Cretaceous planktic foraminifera, 17-86. In Bolli, H.M., Saunders, J.B. \& Perch-Nielsen, K. (eds) Plankton Stratigraphy. University Press, Cambridge.

Christensen, W.K. 1974. Morphometric analysis of Actinocamax plenus from England. Bulletin of the Geological Society of Denmark 23, 1-26.

Christensen, W.K. 1990. Actinocamax primus Arkhangelsky (Belemnitellidae, Upper Cretaceous): Biometry, comparison and biostratigraphy. Paläontologische Zeitschrift 64, 75-90. DOI 10.1007/BF02985923

Combémorel, R., Christensen, W.K., Naidin, D.P. \& Spaeth, C. 1981. Les Belemnites. Cretaceous Research 2, 283-286. DOI 10.1016/0195-6671(81)90017-3

Dietze, H. 1959. Die Inoceramen von Oberau in Sachsen. Obercenoman bis Unterturon. Geologie 8(5), 856-883.

Dietze, H. 1961. Paläontologische und stratigraphische Untersuchungen der Klippenfazies von Oberau und Meißen (Sächsische Oberkreide). Jahrbuch des Staatlichen Museums für Mineralogie und Geologie Dresden 1960, 1-74.

Dölling, B., Dölling, M. \& Hiss, M. 2014. The Upper Cretaceous sedimentary rocks of the southern Münsterland (Northwest Germany) revisited - new correlations of borehole lithostratigraphical, biostratigraphical and natural gamma radiation (GR) log data. Zeitschrift der Deutschen Gesellschaft für Geowissenschaften 165, 521-545.

DuNHAM, R.J. 1962. Classification of carbonate rocks according to depositional texture, 108-121. In HAM, W.E. (ed.) Classification of carbonate rocks. American Association of Petroleum Geologists, Memoir 1. Tulsa.

Ernst, G., Schmid, F. \& Seibertz, E. 1983. Event-Stratigraphie im Cenoman und Turon von NW-Deutschland. Zitteliana 10, 531-554.

FöHLISCH, K. 1998. Palökologie der sandig ausgebildeten Dölzschen-Formation (Oberes Obercenoman) Sachsen. Abhandlungen des Staatlichen Museums für Mineralogie und Geologie zu Dresden 43/44, 141-149.

Freiesleben, J.C. 1836. Magazin für die Oryktographie von Sachsen. Ein Beitrag zur mineralogischen Kenntniß dieses Landes und zur Geschichte seiner Mineralien 7. 313 pp. Engelhardt, Freiberg.

FunK, H. 1971. Zur Stratigraphie und Lithologie des Helvetischen Kieselkalkes und der Altmannschichten in der SäntisChurfirsten-Gruppe (Nordostschweiz). Eclogae Geologicae Helvetiae 64, 345-433.

Gale, A.S. 1995. Cyclostratigraphy and correlation of the Cenomanian stage in Western Europe, 177-197. In House, M.R. \& GaLe, A.S. (eds) Orbital forcing timescales and cyclostratigraphy. Geological Society London, Special Publication 85. 
Gallwitz, H. 1935. Das Pliocän von Oberau in Sachsen. Sitzungsberichte und Abhandlungen der Naturforschenden Gesellschaft ISIS Dresden 19, 82-95.

GeInitz, H.B. 1839. Charakteristik der Schichten und Petrefacten des sächisch-böhmischen Kreidegebirges, sowie der Versteinerungen von Kieslingswalda. Erstes Heft. Der Tunnel bei Oberau in geognostischer Hinsicht, und die dieser Bildung verwandten Ablagerungen zwischen Oberau, Meissen und dem Plauenschen Grunde bei Dresden. 28 pp. Arnold, Dresden.

Geinitz, H.B. 1849. Das Quadersandsteingebirge oder Kreidegebirge in Deutschland. 293 pp. Graz \& Gerlach, Freiberg. DOI 10.5962/bhl.title. 134728

GeINITZ, H.B. 1871-1875. Das Elbthalgebirge in Sachsen. Erster Theil: Der untere Quader. Palaeontographica 20(1), 1-319.

Gerber, C. 1717. Die Unerkannten Wohlthaten Gottes, In dem Chur-Fürstenthum Sachsen, und desselben vornehmsten Städten, darinnen zugleich der Schul- und Kirchen-Staat enthalten, beschrieben von Christian Gerbern, Pastore in Lockwitz bey Dreßden. 1103 pp. Winckler, Dresden \& Leipzig.

Hallam, A. 1992. Phanerozoic sea-level changes. 266 pp. Columbia University Press, New York.

Hancock, J. 2004. The mid-Cenomanian eustatic low. Acta Geologica Polonica 54, 611-627.

Häntzschel, W. 1933. Das Cenoman und die Plenus-Zone der sudetischen Kreide. Abhandlungen der Preußischen Geologischen Landesanstalt, Neue Folge 150, 1-161.

Janetschke, N. \& Wilmsen, M. 2014. Sequence stratigraphy of the lower Upper Cretaceous Elbtal Group (CenomanianTuronian of Saxony, Germany). Zeitschrift der Deutschen Gesellschaft für Geowissenschaften 165, 179-208.

DOI 10.1127/1860-1804/2013/0036

JanetschKe, N., Niebuhr, B. \& Wilmsen, M. 2015. Inter-regional sequence stratigraphical synthesis of the Plänerkalk, Elbtal and Danubian Cretaceous groups (Germany): CenomanianTuronian correlations around the Mid-European Island. Cretaceous Research 56, 530-549.

DOI 10.1016/j.cretres.2015.04.007

Jarvis, I., Gale, A.S., Jenkyns, H.C. \& Pearce, M.A. 2006. Secular variation in Late Cretaceous carbon isotopes: a new $\delta^{13} \mathrm{C}$ carbonate reference curve for the CenomanianCampanian (99.6-70.6 Ma). Geological Magazin 143, 561-608. DOI 10.1017/S0016756806002421

Jarvis, I., Lignum, J.S., Gröcke, D.R., Jenkyns, H.C. \& Pearce, M.A. 2011. Black shale deposition, atmospheric $\mathrm{CO}_{2}$ drawdown, and cooling during the Cenomanian-Turonian Oceanic Anoxic Event. Palaeoceanography 26, PA3201.

JEFFRIES, R.P.S. 1963. The stratigraphy of the Actinocamax plenus subzone (Turonian) in the Anglo-Paris Basin. Proceedings of the Geologists' Association 74(1), 1-33. DOI 10.1016/S0016-7878(63)80011-5

Kley, J. \& Voigt, T. 2008. Late Cretaceous intraplate thrusting in central Europe: Effect of Africa-Iberia-Europoe convergence, not Alpine collision. Geology 36, 839-842. DOI 10.1130/G24930A.1

KöHLER, S. 1988. Scaphites-Fund im Cenoman der sächsischen Kreide. Fundgrube 24(1), p. 27.

KöHLER, S. 1991. Neuer Fund des Ammoniten Schloenbachia varians (Sharpe) in der sächsischen Oberkreide. Fundgrube 1991(2), 83-84.

KöHLER, S. 1993. Bemerkenswerte Cephalopodenfunde aus der sächsischen Oberkreide. Fundgrube 1993(1-2), 37-45.

KöHLER, S. 1996. Zusammengeschwemmte Echiniden aus dem Cenoman von Meißen. Fossilien 1996(3), 167-172.

KöHLER, S. 2001. Turrilites-Nachweis aus dem Untercenoman von Meißen. Fossilien 2001(3), 163-164.

KöHLER, S. 2004. Zwei Hamitensteinkerne aus dem Cenoman von Oberau in Sachsen. Fossilien 2004(5), 311-313.

KöHLER, S. 2012. Ein heteromorpher Ammonit Worthoceras aus dem Cenoman von Oberau in Sachsen. Fossilien 2012(5), 265-266.

KöHLER, S. \& Spaeth, C. 1998. The first belemnite record from the Early Cenomanian conglomerate of Meissen (Saxony). Zentralblatt für Geologie und Paläontologie, Teil I, 1996(11/12), 1487-1488.

KošŤÁA, M. \& PAVLIŠ, W. 1997. Biometric analysis of Praeactinocamax plenus (Blainv.) from the Bohemian Cretaceous Basin. Acta Universitatis Carolinae - Geologica 41(1), $1-13$.

LöSER, H. 1989. Die Korallen der sächsischen Oberkreide (1): Hexacorallia aus dem Cenoman. Abhandlungen des Staatlichen Museums für Mineralogie und Geologie zu Dresden 36, 88-154.

Löser, H. 2014. Korallen, 17-56. In Niebuhr, B. \& Wilmsen, M. (eds) Kreide-Fossilien in Sachsen, Teil 1. Geologica Saxonica 60(1). Dresden.

Mitchell, S.F. 2005. Eight belemnite biohorizons in the Cenomanian of northwest Europe and their importance. Geological Journal 40(3), 363-382. DOI 10.1002/gj.1016

Mitchell, S.F., Paul, C.R.C. \& Gale, A.S. 1996. Carbon isotopes and sequence stratigraphy, 11-24. In Howell, J.A. \& Aitken, J.F. (eds) High resolution sequence stratigraphy: Innovations and applications. Geological Society London, Special Publication 104.

Niebuhr, B., Hiss, M., Kaplan, U., Tröger, K.-A., Voigt, S., Voigt, T., Wiese, F. \& Wilmsen, M. 2007. Lithostratigraphie der norddeutschen Oberkreide. Schriftenreihe der Deutschen Gesellschaft für Geowissenschaften 55. 1-136.

Ortmann, B. 1994. Sedimentationsraten und Redoxpotential im Bereich des Cenomanian-Turonian Anoxic Event: Ichnofazies und Geochemie der Bohrung Gröbern (Sächsische Kreide). 65 pp. Master thesis, TU Bergakademie Freiberg, Germany.

Owen, E.F. 1988. Cenomanian brachiopods from the lower Chalk of Britain and northern Europe. Bulletin of the British Museum, Natural History, Geology Series 44, 67-175.

Paul, C.R.C., Lamolda, M.A., Mitchell, S.F., Vaziri, M.R., Gorostidi, A. \& Marshall, J.D. 1999. The CenomanianTuronian boundary at Eastbourne (Sussex, UK): a proposed European reference section. Palaeogeography, Palaeoclimatology, Palaeoecology 150, 83-121. DOI 10.1016/S0031-0182(99)00009-7

Perch-Nielsen, K. 1985. Mesozoic calcareous nannofossils, 329-426. In Bolli, H.M., Saunders, J.B. \& Perch-Nielsen, K. (eds) Plankton Stratigraphy, Volume 1. Cambridge University Press. 
Petrascheck, W. 1900. Studien über Faciesbildungen im Gebiete der sächsischen Kreideformation. Sitzungsberichte und Abhandlungen der Naturwissenschaftlichen Gesellschaft Isis in Dresden, Jahrgang 1899 (dated 1900), 31-84.

Philip, J. \& Floquet, M. 2000. Late Cenomanian (94.7-93.5), CCGM/CGMW, 129-136. In Dercourt, J., Gaetani, M., Vrielynck, B., Barrier, E., Biju-Duval, B., Brunet, M.F., Cadet, J.P., Crasquin, S. \& Sandulescu, M. (eds) Atlas PeriTethys palaeogeographical maps. Paris.

Prescher, H. 1957. Die Niederschönaer Schichten der sächsischen Kreide. Mit einem Anhang: Erläuterungen zur Karte des Cenomans und Turons im sächsischen Elbtalgebiet. Freiberger Forschungshefte C 34, 1-96.

Prescher, H. \& Tröger, K.-A. 1989. Die "Meißner Schichten" der sächsischen Kreide (Forschungsgeschichte, Litho- und Biostratigraphie). Abhandlungen des Staatlichen Museums für Mineralogie und Geologie Dresden 36, 155-167.

Preuss, R. 1985. Der Oberauer Tunnel - Aufbau und Abbruch. Modelleisenbahner - Eisenbahn-Modellbahn-Zeitschrift 34(12), 14-16.

ReINISCH, R. 1928. Erläuterungen zur geologischen Karte von Sachsen 1:25.000, Blatt 48 Meißen (3. Auflage). 136 pp. Engelmann, Leipzig.

Richardt, N. \& Wilmsen, M. 2012. Lower Upper Cretaceous standard section of the southern Münsterland (NWGermany): carbon stable isotopes and sequence stratigraphy. Newsletters on Stratigraphy 45, 1-24. DOI 10.1127/0078-0421/2012/0012

Robaszynski, F. \& CARON, M. 1979a. Atlas de foraminifères planctoniques du Cetétacé moyen (mer boréale et Téthys). Part 1. Cahiers de Micropaléontologie 1, 1-181.

Robaszynski, F. \& CARON, M. 1979b. Atlas de foraminifères planctoniques du Cetétacé moyen (mer boréale et Téthys). Part 2. Cahiers de Micropaléontogie 2, 1-185.

Robaszynski, F., Juignet, P., Gale, A.S., Amédro, F. \& Hardenbol, J. 1998. Sequence stratigraphy in the Cretaceous of the Anglo-Paris Basin, exemplified by the Cenomanian stage, 363-385. In Jaquin, T., Graciansky, P. dE \& HardenBOL, J. (eds) Mesozoic and Cenozoic sequence stratigraphy of European basins. Society of Economic Palaeontologists \& Mineralogists Special Publication 60. Tulsa.

RompF, I. 1960. Foraminiferen aus dem Cenoman von Sachsen, unter besonderer Berücksichtigung der Umgebung von Dresden. Freiberger Forschungshefte C 89, 1-123.

Roth, P.H. 1978. Cretaceous Nannoplankton Biostratigraphy and Oceanography of the Northwestern Atlantic Ocean, 731-759. In Benson, W.E. \& Sheridan, R.E. (eds) Initial Reports of the Deep Sea Drilling Project 62.

DOI 10.2973/dsdp.proc.44.134.1978

Salvador, A. (ed.) 1994. International stratigraphic guide. A guide to stratigraphic classification, terminology and procedure, $2^{\text {nd }}$ edition. 214 pp. IUGS/GSA, Boulder.

Schander, H. 1923. Die cenomane Transgression im mittleren Elbtalgebiet. Geologisches Archiv 2, 49-96.

Schlanger, S.O. \& Jenkyns, H.C. 1976. Cretaceous oceanic anoxic events: Causes and consequences. Geologie en Mijnbouw 55(3-4), 179-184.

Schlanger, S.O., Arthur, M.A., Jenkyns, H.C. \& Scholle, P.A.
1987. The Cenomanian-Turonian Oceanic Anoxic Event. Stratigraphy and distribution of organic carbon-rich beds and the marine $\delta^{13} \mathrm{C}$-excursion, 371-399. In Brooks, J. \& FLeEt, A.J. (eds) Marine Petroleum Source Rocks. Geological Society, Special Publication 26.

SchneIDER, C.G. 1843. Beschreibung des Tunnels der LeipzigDresdner Eisenbahn. Zeitschrift für Praktische Baukunst 1843(3), 6-41.

Shamrock, J.L. \& Watkins, D.K. 2009. Evolution of the Cretaceous calcareous nannofossil genus Eiffellithus and its biostratigraphic significance. Cretaceous Research 30, 1083-1102. DOI 10.1016/j.cretres.2009.03.009

Shanley, K.W. \& McCabe, P.J. 1993. Alluvial architecture in a sequence stratigraphic framework: a case history from the Upper Cretaceous of southern Utah, U.S.A., 21-55. In FLINT, S. $\&$ BRYANT, I. (eds) Quantitative modelling of clastic hydrocarbon reservoirs and outcrop analogues. International Association of Sedimentologists Special Publication 15. Oxford.

Siegert, T. 1906. Section Kötzschenbroda-Oberau. Erläuterungen zur geologischen Specialkarte des Königreichs Sachsen, Blatt 49 (2. Auflage), 1-64.

Spaeth, C. \& Köhler, S. 1997. Erstnachweis eines Belemniten aus dem Untercenoman von Meißen, Sachsen. Fossilien 1997(4), 225-226.

ŠpiČÁKovÁ, L., UličnÝ, D. \& SvobodovÁ, M. 2014. Phases of the mid-Cenomanian transgression recorded in a composite palaeovalley fill - the Horoušany quarry, Bohemian Cretaceous Basin. Zeitschrift der Deutschen Gesellschaft für Geowissenschaften 165, 581-619.

DOI 10.1127/zdgg/2014/0028

Steininger, F.F. \& Piller, W.E. 1999. Empfehlungen (Richtlinien) zur Handhabung der stratigraphischen Nomenklatur. Courier Forschungsinstitut Senckenberg 209, 1-19.

ThiersteIn, H.R. 1980. Selective Dissolution of Late Cretaceous and Earliest Tertiary Calcareous Nannofossils: Experimental Evidence. Cretaceous Research 2, 165-176.

DOI 10.1016/0195-6671(80)90023-3

TRÖGER, K.-A. 1955. Über die Kreideablagerungen des Plauenschen Grundes (sedimentpetrographische und biostratinomisch-paläontologische Untersuchungen). Jahrbuch des Staatlichen Museums für Mineralogie und Geologie Dresden 2, 22-124.

Tröger, K.-A. 1988. Zur Bio- und Lithostratigraphie der Brießnitzer Schichten bei Dresden. Freiberger Forschungshefte C 419, 89-95.

TRÖGER K.-A. 1989. Eine obercenomane Foraminiferen-Fauna aus den Mergeln von Meißen-Zscheila. Zeitschrift für geologische Wissenschaften 17, 989-998.

TRÖGER K.-A. 2003. The Cretaceous of the Elbe valley in Saxonya review. Carnets de Géologie A03, 1-14.

DOI 10.4267/2042/295

TRÖGER, K.-A. 2008. Kreide - Oberkreide, 311-358. In PäLCHEN, W. \& Walter, H. (eds) Geologie von Sachsen. Geologischer Bau und Entwicklungsgeschichte. Schweizerbart, Stuttgart.

TRÖGER, K.-A. 2009. Katalog oberkretazischer Inoceramen. Geologica Saxonica 55,1-188.

Tröger, K.-A. 2015. Obercenomane Inoceramen aus der sächsischen Kreide. Geologica Saxonica 60(3), 377-425. 
Tröger, K.-A. 2017. Facies changes in the Cenomanian (Cretaceous) of the northwestern Elbe Valley near Dresden (Saxony, Germany). Acta Geologica Polonica 67, 135-144. DOI 10.1515/agp-2017-0008

Tröger, K.-A. \& Niebuhr, B. 2014. Inoceramen, 169-200. In Niebuhr, B. \& Wilmsen, M. (eds) Kreide-Fossilien in Sachsen, Teil 1. Geologica Saxonica 60(1).

TRÖGER, K.-A. \& VoIGT, T. 1995. Event- und Sequenzstratigraphie in der Sächsischen Kreide. Berliner geowissenschaftliche Abhandlungen E 16(1), 255-267.

Tröger, K.-A. \& Wolf, L. 1960. Zur Stratigraphie und Petrographie der Strehlener Schichten. Geologie 9, 288-298.

Tröger, K.-A., Voigt, T., Wejda, M., Pilot, J., Starke, R., Kleeberg, R. \& Klemm, W. 1996. Multistratigraphic investigation of Cenomanian to Coniacian sequences using a W-E profile between Münsterland and Saxony - part Saxony, 139-145. In Reitner, J., Neuweiler, F. \& Gunkel, F. (eds) Global and regional controls on biogenic sedimentation. II. Cretaceous Sedimentation. Research Reports. Göttinger Arbeiten für Geologie und Paläontologie Sonderband 3. Göttingen.

ULIČNÝ, D. \& ŠPIČÁKOVÁ, L. 1996. Response to high frequency sea-level change in a fluvial to estuarine succession: Cenomanian palaeovalley fill, Bohemian Cretaceous Basin, 247-268. In Howell, J.A. \& AitKen, J.F. (eds), High resolution sequence stratigraphy: Innovations and applications. Geological Society London, Special Publication 104.

UličnÝ, D., HLadíkovÁ, J. \& HradeckÁ, L. 1993. Record of sealevel changes, oxygen depletion and the $\delta^{13} \mathrm{C}$ anomaly across the Cenomanian-Turonian boundary, Bohemian Cretaceous Basin. Cretaceous Research 14, 211-234.

DOI 10.1006/cres.1993.1015

UličnÝ, D., ŠpičÁkovÁ, L., Grygar, R., SvobodovÁ, M., ČECh, S. \& Laurin, J. 2009. Palaeodrainage systems at the basal unconformity of the Bohemian Cretaceous Basin: roles of inherited fault systems and basement lithology during the onset of basin filling. Bulletin of Geosciences 84(4), 577-610. DOI 10.3140/bull.geosci.1128

Vejbek, O.V., Andersen, C., Dusa, M., Herngreen, W., KrabBe, H., Leszczynski, K., Lott, G.K., Mutterlose, J., van Der Molen, A.S. 2010. Cretaceous, 195-209. In Doornenbal, H. \& Stevenson, A. (eds) Petroleum Geological Atlas of the Southern Permian Basin Area. EAGE Publications. Houten.

VoIGt, T. 1994. Faziesentwicklung und Ablagerungssequenzen am Rand eines Epikontinentalmeeres - die Sedimentationsgeschichte der Sächsischen Kreide. 130 pp. Ph.D. thesis, TU Bergakademie Freiberg, Germany.

VoIgt, T. 1998. Entwicklung und Architektur einer fluviatilen Talfüllung - die Niederschöna Formation im Sächsischen Kreidebecken. Abhandlungen des Staatlichen Museums für Mineralogie und Geologie zu Dresden 43/44, 121-139.

Voigt, T. 1999. Ablagerungsbedingungen und Taphonomie der Schmilka-Formation (Unter-Turon) südlich von Pirna (Sächsisches Kreidebecken). Greifswalder geowissenschaftliche Beiträge 6, 193-207.

VoIGt, T. 2007. Die geologische Entwicklung der Elbtalkreide, 3-12. In Siedel, H., Franzen, C. \& Weise, S. (eds) Elb- sandstein. Institut für Diagnostik und Konservierung von Denkmalen in Sachsen und Sachsen-Anhalt e.V., Dresden.

Voigt, T. 2009. Die Lausitz-Riesengebirgs-Antiklinalzone als kreidezeitliche Inversionsstruktur: Geologische Hinweise aus den umgebenden Kreidebecken. Zeitschrift für geologische Wissenschaften 37, 15-39.

Voigt, T. 2011. Sturmdominierte Sedimentation in der Postelwitz-Formation (Turon) der Sächsischen Kreide. Freiberger Forschungshefte C 540, 3-25.

Voigt, T. \& Tröger, K.-A. 1996. Sea-level changes during the Late Cenomanian and Early Turonian in the Saxonian Cretaceous Basin, 275-290. In SpaEth, C. (ed.) New Developments in Cretaceous Research Topics. Proceedings of the $4^{\text {th }}$ International Cretaceous Symposium 1992. Mitteilungen aus dem Geologisch-Paläontologischen Institut der Universität Hamburg 77. Hamburg.

Voigt, S., Gale, A.S. \& Voigt, T. 2006. Sea-level changes, carbon cycling and palaeoclimate during the Late Cenomanian of northwest Europe; an integrated palaeoenvironmental analysis. Cretaceous Research 27, 836-858.

DOI 10.1016/j.cretres.2006.04.005

Voigt, T., Voigt, S. \& Tröger, K.-A. 1994. Faziesentwicklung einer ertrunkenen Felsküste - die obercenomane Monzonitklippe westlich von Dresden. Freiberger Forschungshefte $C$ 452, 23-34.

Voigt, S., Erbacher, J., Mutterlose, J., Weiss, W., Westerhold, T., Wiese, F., Wilmsen, M. \& Wonik, T. 2008. The Cenomanian-Turonian of the Wunstorf section (North Germany): global stratigraphic reference section and new orbital time scale for Oceanic Anoxic Event 2. Newsletter on Stratigraphy 43, 65-89. DOI 10.1127/0078-0421/2008/0043-0065

Wiese, F., KošŤÁk, M. \& Wood, C.J. 2009. The Upper Cretaceous belemnite Praeactinocamax plenus (Blainville, 1827) from Lower Saxony (Upper Cenomanian, northwest Germany) and its distribution pattern in Europe. Paläontologische Zeitschrift 83, 309-321. DOI 10.1007/s12542-009-0022-8

Wiese, F., Čech, S., EKrt, B., KošŤÁK, M., MaZuch, M. \& Voigt, S. 2004. The Upper Turonian of the Bohemian Cretaceous Basin (Czech Republic) exemplified by the Úpohlavy working quarry: integrated stratigraphy and palaeoceanography of a gateway to the Tethys. Cretaceous Research 25, 329-352. DOI 10.1016/j.cretres.2004.01.003

Wilmsen, M. 1999. The Cretaceous belemnite Neohibolites ultimus (d'Orbigny, 1845): Its occurrence and significance in the Cenomanian of the North Cantabrian Basin. Neues Jahrbuch für Geologie und Paläontologie, Monatshefte 5, 295-311.

Wilmsen, M. 2003. Sequence stratigraphy and palaeoceanography of the Cenomanian Stage in northern Germany. Cretaceous Research 24, 525-568.

DOI 10.1016/S0195-6671(03)00069-7

WiLMSEN, M. 2007. Integrated stratigraphy of the upper Lowerlower Middle Cenomanian of northern Germany and southern England. Acta Geologica Polonica 57, 263-279.

Wilmsen, M. 2012. Origin and significance of Upper Cretaceous bioevents: Examples from the Cenomanian. Acta Palaeontologica Polonica 57, 759-771.

DOI 10.4202/app.2011.0044 
Wilmsen, M. 2014. Belemniten, 241-248. In Niebuhr, B. \& Wilmsen, M. (eds) Kreide-Fossilien in Sachsen, Teil 1. Geologica Saxonica, 60(1). Dresden.

Wilmsen, M. 2017. Macroinvertebrate fauna and depositional environment of the lower Upper Cenomanian Oberhäslich Formation in the Saxonian Cretaceous Basin (Germany). Annales de Paléontologie 103, 33-44. DOI 10.1016/j.annpal.2016.11.003

Wilmsen, M. \& Mosavinia, A. 2011. Phenotypic plasticity and taxonomy of Schloenbachia varians (J. Sowerby, 1817). Paläontologische Zeitschrift 85, 169-184. DOI 10.1007/s12542-010-0086-5

Wilmsen, M. \& Nagm, E. 2013. Upper Cenomanian-Lower Turonian ammonoids from the Saxonian Cretaceous (lower Elbtal Group, Saxony, Germany). Bulletin of Geosciences 88, 647-674. DOI 10.3140/bull.geosci.1390

Wilmsen, M. \& Nagm, E. 2014. Ammoniten, 201-240. In Niebuhr, B. \& Wilmsen, M. (eds) Kreide-Fossilien in Sachsen, Teil 1. Geologica Saxonica, 60(1). Dresden.

Wilmsen, M. \& Niebuhr, B. 2002. Stratigraphic revision of the upper Lower and Middle Cenomanian in the Lower Saxony Basin (northern Germany) with special reference to the Salzgitter area. Cretaceous Research 23(4), 445-460. DOI 10.1006/cres.2002.1014

Wilmsen, M. \& Niebuhr, B. 2014. Die Kreide in Sachsen, 3-12. In Niebuhr, B. \& Wilmsen, M. (eds) Kreide-Fossilien in Sachsen, Teil 1. Geologica Saxonica, 60(1). Dresden.

Wilmsen, M. \& Rabe, M. 2008. Belemnites from the lower Middle Cenomanian of Hoppenstedt, northern Germany: significance and integrated correlation. Cretaceous Research 29, 936-942. DOI 10.1016/j.cretres.2008.05.013

Wilmsen, M. \& Wood, C.J. 2004. The Cenomanian of Hoppen- stedt, northern Germany: a Subhercynian key section revisited. Newletters on Stratigraphy 40(3), 209-230. DOI 10.1127/0078-0421/2004/0040-0209

Wilmsen, M., VodrážKa, R. \& Niebuhr, B. 2011. The Upper Cenomanian and Lower Turonian of Lockwitz (Dresden area, Saxony, Germany): lithofacies, stratigraphy and fauna of a transgressive succession. Freiberger Forschungshefte $C$ 540, 27-45.

Wilmsen, M., Niebuhr, B., Wood, C.J. \& Zawischa, D. 2007. Fauna and palaeoecology of the Middle Cenomanian Praeactinocamax primus Event at the type locality, Wunstorf quarry, northern Germany. Cretaceous Research 28(3), 428-460. DOI 10.1016/j.cretres.2006.07.004

Woods, H. 1899-1913. A monograph of the Cretaceous Lamellibranchia of England. The Palaeontographical Society London 1, 232 pp. The Palaeontographical Society London 2, 473 pp.

Wright, C.J. \& Kennedy, W.J. 1995. The Ammonoidea of the Lower Chalk. Part 4. The Palaeontographical Society Monograph 599(149), 295-319.

Wright, C.J. \& Kennedy, W.J. 1996. The Ammonoidea of the Lower Chalk. Part 5. The Palaeontographical Society Monograph 601(150), 320-403.

Wright, C.J. \& Kennedy, W.J. 2017. The Ammonoidea of the Lower Chalk. Part 7. The Palaeontographical Society Monograph 648(171), 461-561.

DOI 10.1080/02693445.2017.11963959

Young, J.R., Bown, P.R. \& LeEs, J.A. 2018. Nannotax3 website. International Nannoplankton Association. Accessed 15.06.18. http//www.mikrotax.org/Nannotax3

Ziegler, P.A. 1990. Geological Atlas of Western and Central Europe. $2^{\text {nd }}$ edition. 239 pp. Shell Internationale Petroleum Maatschappij BV, The Hague. 
Appendix. Taxonomic index of nannofossils mentioned in the text in alphabetical order of genera names.

Amphizygus brooksii Bukry, 1969

Axopodorhabdus albianus (Black, 1967) Wind \& Wise, 1983

Bilapillus wadeae Lees 2007

Biscutum constans (Górka, 1957) Black in Black \& Barnes, 1959

Braarudosphaera bigelowii (Gran \& Braarud, 1935) Deflandre, 1947

Broinsonia cenomanica (Black, 1973) Bown 2001

Broinsonia enormis (Shumenko, 1968) Manivit, 1971

Broinsonia furtiva (Bukry, 1969) Wind \& Wise, 1980

Broinsonia matalosa (Stover, 1966) Burnett in Gale et al., 1996

Broinsonia signata (Noël, 1969) Noël, 1970

Bukrylithus ambiguus Black, 1971

Calciosolenia fossilis (Deflandre in Deflandre \& Fert, 1954)

Bown in Kennedy et al. 2000

Calculites cenomanicus (Jakubowski, 1986) Varol \& Jakubowski, 1989

Calculites obscurus (Deflandre, 1959) Prins \& Sissingh in Sissingh, 1977

Chiastozygus bifarius Bukry, 1969

Chiastozygus litterarius (Górka, 1957) Manivit, 1971

Chiastozygus spissus Bergen in Bralower \& Bergen, 1998

Chiastozygus synquadriperforatus Bukry, 1969

Corollithion exiguum Stradner, 1961

Corollithion kennedyi Crux, 1981

Corollithion signum Stradner, 1963

Cretarhabdus conicus Bramlette \& Martini, 1964

Cretarhabdus striatus (Stradner, 1963) Black, 1973

Cribrosphaerella ehrenbergii (Arkhangelsky, 1912) Deflandre in Piveteau, 1952

Cyclagelosphaera margerelii Noël, 1965

Cylindralithus biarcus Bukry, 1969

Cylindralithus sculptus Bukry, 1969

Discorhabdus ignotus (Górka, 1957) Perch-Nielsen, 1968

Eiffellithus casulus Shamrock in Shamrock \& Watkins 2009

Eiffellithus parvus Watkins \& Bergen 2003

Eiffellithus turriseiffelii (Deflandre in Deflandre \& Fert, 1954)

Reinhardt, 1965

Eprolithus apertior Black, 1973

Eprolithus floralis (Stradner, 1962) Stover, 1966

Eprolithus moratus (Stover, 1966) Burnett, 1998

Eprolithus octopetalus Varol, 1992

Eprolithus rarus Varol, 1992

Flabellites oblongus (Bukry, 1969) Crux in Crux et al., 1982

Gartnerago chiasta (Varol, 1991)

Gartnerago coxalliae Lees 2007

Gartnerago obliquum (Stradner, 1963) Noël, 1970

Gartnerago praeobliquum Jakubowski, 1986

Gartnerago segmentatum (Stover, 1966) Thierstein, 1974

Gartnerago theta (Black in Black \& Barnes, 1959) Jakubowski, 1986

Grantarhabdus coronadventis (Reinhardt, 1966) Grün in Grün \& Allemann, 1975

Haqius circumradiatus (Stover, 1966) Roth, 1978

Helenea chiastia Worsley, 1971

Helicolithus anceps (Górka, 1957) Noël, 1970

Helicolithus compactus (Bukry, 1969) Varol \& Girgis, 1994

Helicolithus trabeculatus (Górka, 1957) Verbeek, 1977

Lithraphidites acutus Verbeek \& Manivit in Manivit et al., 1977
Lithraphidites carniolensis Deflandre, 1963

Manivitella pemmatoidea (Deflandre in Manivit, 1965) Thierstein, 1971

Micrantolithus obtusus Stradner, 1963

Microrhabdulus decoratus Deflandre, 1959

Microrhabdulus helicoideus Deflandre, 1959

Owenia hillii Crux, 1991

Prediscosphaera columnata (Stover, 1966) Perch-Nielsen, 1984

Prediscosphaera cretacea (Arkhangelsky, 1912) Gartner, 1968

Prediscosphaera spinosa (Bramlette \& Martini, 1964) Gartner, 1968

Quadrum intermedium Varol, 1992

Quadrum octobrachium Varol, 1992

Radiolithus orbiculatus (Forchheimer, 1972) Varol, 1992

Radiolithus planus Stover, 1966

Retecapsa angustiforata Black, 1971

Retecapsa crenulata (Bramlette \& Martini, 1964) Grün in Grün \& Allemann, 1975

Retecapsa ficula (Stover, 1966) Burnett, 1997

Retecapsa octofenestrata (Bralower in Bralower et al., 1989) Bown in Bown \& Cooper, 1998

Retecapsa surirella (Deflandre \& Fert, 1954) Grün in Grün \& Allemann, 1975

Rhagodiscus achlyostaurion (Hill, 1976) Doeven, 1983

Rhagodiscus angustus (Stradner, 1963) Reinhardt, 1971

Rhagodiscus asper (Stradner, 1963) Reinhardt, 1967

Rhagodiscus splendens (Deflandre, 1953) Verbeek, 1977

Rotelapillus crenulatus (Stover, 1966) Perch-Nielsen, 1984

Sollasites horticus (Stradner et al. in Stradner \& Adamiker, 1966) Cepek \& Hay, 1969

Staurolithites ellipticus (Gartner, 1968) Lambert, 1987

Staurolithites gausorhethium (Hill, 1976) Varol \& Girgis, 1994

Staurolithites laffittei Caratini, 1963

Stoverius achylosus (Stover, 1966) Perch-Nielsen, 1986

Tegumentum stradneri Thierstein in Roth \& Thierstein, 1972

Tetrapodorhabdus decorus (Deflandre in Deflandre \& Fert, 1954) Wind \& Wise, 1983

Tranolithus gabalus Stover, 1966

Tranolithus minimus (Bukry, 1969) Perch-Nielsen, 1984

Tranolithus orionatus (Reinhardt, 1966a) Reinhardt, 1966b

Watznaueria barnesiae (Black in Black \& Barnes, 1959) PerchNielsen, 1968

Watznaueria biporta Bukry, 1969

Watznaueria britannica (Stradner, 1963) Reinhardt, 1964

Watznaueria ovata Bukry, 1969

Zeugrhabdotus acanthus Reinhardt, 1965

Zeugrhabdotus bicrescenticus (Stover, 1966) Burnett in Gale et al., 1996

Zeugrhabdotus clarus Bown 2005

Zeugrhabdotus diplogrammus (Deflandre in Deflandre \& Fert, 1954) Burnett in Gale et al., 1996

Zeugrhabdotus embergeri (Noël, 1959) Perch-Nielsen, 1984

Zeugrhabdotus erectus (Deflandre in Deflandre \& Fert, 1954) Reinhardt, 1965

Zeugrhabdotus howei Bown in Kennedy et al. 2000

Zeugrhabdotus noeliae Rood et al., 1971

Zeugrhabdotus scutula (Bergen, 1994) Rutledge \& Bown, 1996 